Article

\title{
On the Distinct Effects of Left-Wing and Right-Wing Populism on Democratic Quality
}

\author{
Robert A. Huber ${ }^{1}$ and Christian H. Schimpf ${ }^{2, *}$ \\ ${ }^{1}$ International Relations, ETH Zurich, 8092 Zurich, Switzerland; E-Mail: robert.huber@ir.gess.ethz.ch \\ ${ }^{2}$ GESIS Leibniz Institute for the Social Sciences, D-68072 Mannheim, Germany; E-Mail: christian.schimpf@gesis.org \\ * Corresponding author
}

Submitted: 16 February 2017 | Accepted: 9 October | Published: 29 December 2017

\begin{abstract}
This study examines the differences and commonalities of how populist parties of the left and right relate to democracy. The focus is narrowed to the relationship between these parties and two aspects of democratic quality, minority rights and mutual constraints. Our argument is twofold: first, we contend that populist parties can exert distinct influences on minority rights, depending on whether they are left-wing or right-wing populist parties. Second, by contrast, we propose that the association between populist parties and mutual constraints is a consequence of the populist element and thus, we expect no differences between the left-wing and right-wing parties. We test our expectations against data from 30 European countries between 1990 and 2012. Our empirical findings support the argument for the proposed differences regarding minority rights and, to a lesser extent, the proposed similarities regarding mutual constraints. Therefore we conclude that, when examining the relationship between populism and democracy, populism should not be considered in isolation from its host ideology.
\end{abstract}

\section{Keywords}

Europe; liberal democracy; minority rights; mutual constraints; political inclusion; populism

\section{Issue}

This article is part of the issue "Populism and the Remaking of (II)Liberal Democracy in Europe", edited by Lars Rensmann (University of Groningen, The Netherlands), Sarah L. de Lange (University of Amsterdam, The Netherlands) and Stefan Couperus (University of Groningen, The Netherlands).

(C) 2017 by the authors; licensee Cogitatio (Lisbon, Portugal). This article is licensed under a Creative Commons Attribution 4.0 International License (CC BY).

\section{Introduction}

Populist actors around the world have gradually evolved into influential political forces in various countries and regions. Independent of the region, they share the ideas of anti-elitism and people centrism. On this basis, they can challenge common democratic rules, including those of liberal democracy (Plattner, 2010), according to which power must be restrained and individual rights protected. Through the populist lens, features of liberal democracy, such as systems of checks and balances, undermine the proper implementation of the general will, which they claim to be the only true representative of. Thus, their presence can have a negative impact on the quality of democracy if populist parties challenge these institutions, particularly when they are in government (Albertazzi \& Mueller, 2013).

Populist parties, however, are not only characterized by their populist element but also by their host ideology (Mudde, 2004). Thus, they can take the form of rightwing populist parties (Mudde, 2007), left-wing populist parties (March, 2011), or centrist populist parties (Havlík \& Stanley, 2015). In other words, populist parties differ on a wide-ranging set of issues such as the promotion of exclusive (right-wing populist parties) or inclusive (left-wing populist parties) societies (Mudde \& Rovira Kaltwasser, 2013). These differences have been shown to manifest themselves in the behavior of populist par- 
ties, for instance with regards to parliamentary voting where the populist element plays little to no role (Otjes \& Louwerse, 2015). Despite these well-known differences, however, there is little debate in the literature about whether the postulated relationship between populist parties and democracy is a function of their host ideology, their populist element, or both. This article seeks to fill this void, taking as its starting point the discussion between populism and liberal democracy (Mudde \& Rovira Kaltwasser, 2012).

We adopt the proposition that the host ideology, like the populist element, is central to the actions that parties take. We argue that the role of ideology is essential to understanding why populist parties of varying host ideologies relate differently to subdimensions of liberal democracy, namely political inclusion (minority rights) and mutual constraints. Focusing on left-wing and rightwing populist parties, we anticipate the host ideology to be the deciding factor for how these parties relate to the dimension of political inclusion. In comparison to rightwing populist parties, we expect left-wing populist parties to be associated with more positive effects on minority rights. For the second dimension, mutual constraints, we expect the populist element to play the central role and in consequence, expect no differences in associations between populist parties of different host ideology.

Empirically, we test our propositions against data from 30 European countries from 1990 to 2012. This dataset, although limited to one region, allows us to test our arguments for a diverse set of populist parties. The results lend support to our argument that host ideologies matter for how certain populist parties relate to democracy and liberal democracy in particular as differences in effects of left and right-wing populists occur for minority rights. At the same time, the results do not suggest a strong association between populist parties and mutual constraints. Therefore, this study highlights the need to investigate subdimensions of (liberal) democracy (Houle \& Kenny, 2016; Immerzeel \& Pickup, 2015) to generate a better understanding of the complex relationship between populist parties and democracy.

\section{Populism and (Liberal) Democracy}

Following the ideational approach (Hawkins, 2009), populism constitutes a set of ideas. Despite varying definitions that can be subsumed under the ideational approach, most studies consider at least four attributes central to populism: people centrism, the perception of the people as a homogenous entity with a general will, antielitism, and the depiction of a permanent crisis (Rooduijn, 2014). Mudde (2004, p. 543; italics original) summarizes the central attributes in his widely referenced minimal definition of populism, which we draw on in this article, calling populism a thin-centered "ideology that considers society to be ultimately separated into two homogeneous and antagonistic groups, 'the pure people' and 'the corrupt elite', and which argues that politics should be an expression of volonté générale (general will) of the people". The view of populism as an ideological construct, however, remains at the center of many debates. Another large branch in the literature, for instance, discusses populism as a discourse (or frame) (e.g., Aslanidis, 2016, 2017; Jagers \& Walgrave, 2007). However, even among those that speak of populism as a discourse, some acknowledge that populists ultimately may implement their idea of politics as an expression of the general will (Müller, 2016). Furthermore, both branches in the literature share the view that populism can appear across the ideological spectrum giving populism its chameleon characteristic (Taggart, 2000). In the ideological approach, for instance, populism as a thin-ideology is said to attach itself to different host ideologies (Stanley, 2008).

Because "populism indirectly questions the procedural minimum that lies at the heart of our current definitions of democracy" (Hawkins, 2010, p. 37), scholars using different conceptualizations discuss the relationship between populism and (certain forms of) democracy. Most notably, they focus on how populism relates to democracy in general (Müller, 2016), representative democracy (Canovan, 1999), and liberal democracy (Kriesi, 2014; Mudde \& Rovira Kaltwasser, 2012; Plattner, 2010). These studies share a focus on populism's homogenous view of society in which the common will of the people is to be articulated in an unmediated way and implemented without any restrictions (Caramani, 2017). ${ }^{1}$ Perhaps for this reason, there has been a recent focus on populism and the quality of liberal democracy (cf. Huber \& Schimpf, 2016a, 2017; Pappas, 2014, 2016). After all, the essence of liberal democracy is that power can never be absolute as it is characterized by "the intrinsic importance of transparency, civil liberty, the rule of law, horizontal accountability (effective checks on rulers), and minority rights" (Coppedge et al., 2011, p. 253). ${ }^{2}$ Minority rights and horizontal accountability in particular are two features of liberal democracy that run counter to the populist understanding of how democracy ought to function. Populist actors depict a homogenous society (the people) and highlight the necessity for politics to follow the general will without any unnecessary restrictions, implemented by the populists themselves as the only true representatives of the people. ${ }^{3}$ Therefore, some scholars argue that populist actors can have a negative impact on democracy, and in particular, on liberal

\footnotetext{
${ }^{1}$ In contrast to extremist parties, radical populist parties are not considered anti-constitutional per se (Mudde, 2007; Rensmann, 2006) although they present the system they operate in as "undemocratic" (Abts \& Rummens, 2007).

2 Democratic quality in this case refers to the degree-and not the existence-of these criteria, that is, how well standards for aspects such as transparency, legality, and good governance are implemented (Beetham, 2004; Diamond \& Morlino, 2005).

3 For this reason, too, Canovan (1999) argues that populism is at odds with representative democracy in which institutions mediate any societal conflicts. Populist actors, however, consider society to be homogenous to begin with and also, may argue in favor of a more direct form of politics (but see Müller, 2016, p. 29 for a different view).
} 
democracy (e.g. Mudde \& Rovira Kaltwasser, 2012; Ruth, 2017). For as long as populists are not in power, they are rarely in a position to implement their ideas. Instead, they may even have a corrective function as they highlight institutional shortcomings (e.g. Müller, 2002), mobilize otherwise unrepresented groups of voters (e.g. Hanley, 2012), and articulate issues or protest (e.g. de Lange \& Akkerman, 2012). ${ }^{4}$

From this debate, we can derive the expectation that populist actors may have positive side effects but generally, relate negatively to (liberal) democratic quality, in particular when they are in government (Albertazzi \& Mueller, 2013). Here, their presence can result in changes or even the erosion of important components such as the system of checks and balances, as can be seen in countries governed by populist parties, such as contemporary Poland (Markowski, 2016) and Hungary (Batory, 2016). However, the argument hinges on the assumption that all populist actors must share a similar understanding of a homogenous society whose general will functions as the guiding principle for political decisions and shall not be infringed by unnecessary institutional boundaries. In this scenario, the people constitute the sovereign. Yet Mény and Surel (2002) identify two further conceptions of the people, namely the people as a nation (cultural) and the people as a class (economic). Both are linked to specific forms of populism, the former to right-wing populism and the latter to left-wing populism (Kriesi, 2014, p. 362). Studies that compare these two types of populist parties find that their behavior, such as their parliamentary voting behavior (Otjes \& Louwerse, 2015) for instance, differs as a consequence of the host ideology. The questions that arise then are: which of the two elements, host ideology or populism, determines the relationship between populism and liberal-democracy? And, does this relationship play out differently depending on the subdimensions of liberal democracy? In what follows, we discuss the differences between left- and right-wing populism in detail. We focus on two aspects of liberal democracy, minority rights and mutual constraints, to highlight possible commonalities and differences in the relationships between populist parties and democracy.

\section{Populism Left, Right, and Center: Differences and Commonalities}

Populist parties, independent of their host ideology, are united in their critique against the political establishment (Rooduijn \& Akkerman, 2017). Yet, it is the host ideology that determines against whom the people should rally
(Katsambekis, 2017, p. 205). Left-wing populist parties define the people on a class basis, referring mostly to the poor. In contrast, right-wing populist parties define the people on a cultural, nativist base (March, 2011; Mudde, 2004). In other words, whereas left-wing populist parties frame their criticisms economically and seek to protect the proletariat from exploitation by capitalists, rightwing populist parties champion nativism (Mudde, 2007, p. 19) and seek to protect "the nation from dangerous others" (Rooduijn \& Akkerman, 2017, p. 196), stressing cultural issues above the rest. Thus, left-wing populist parties differ from right-wing populist parties in that they embrace an inclusive as opposed to an exclusive view of society (Katsambekis, 2017; Mudde \& Rovira Kaltwasser, 2013). ${ }^{5}$ More importantly though, despite left-wing populist being inclusive on the society level, this does not necessarily imply that they are not anti-pluralistic on the political level. Essentially, the question of how democracy is organized is political and differences between leftwing and right-wing populism can be illustrated focusing on central aspects of democracy, namely political inclusion and political contestation (Dahl, 1971). While left-wing populist parties generally neither discredit minority groups nor object to granting these groups political rights, they do not accept political competition for that they, and only they, are the true representatives of the people. Consequently, they consider political control through effective opposition and institutional power check mechanisms as obstacles that prevent them from implementing the people's will. In this sense, left-wing populists are inclusive on the society level and the dimension of political participation. Yet, they are exclusive and essentially anti-pluralistic with regards to public contestation and the control of power (Mudde \& Rovira Kaltwasser, 2013, p. 162). In contrast, right-wing populist parties are generally exclusive with regards to all of these aspects for that they object the extension of political participation rights to minorities in addition to claiming to be the only true representatives of what they consider to be the people. In short, left- and right-wing populism differ with regards to political inclusion but share similarities in their ideas of political contestation and control of power. It is for this reason that we choose two subdimensions of liberal democracy to highlight differences and commonalities between left- and right-wing populism, minority rights and mutual constraints.

\subsection{Minority Rights}

We define minority rights as descriptive representation of minorities in the political system, that is, the absence

\footnotetext{
${ }^{4}$ This positive view, however, is not shared by all authors (e.g., Müller, 2016). After all, any new party in opposition is likely to mobilize new voters and critique established political actors, possibly increasing accountability. Thus, these byproducts can be positive but are not necessarily a function of populism (Huber \& Schimpf, 2016a, p. 109).

${ }^{5}$ Between these two types, we can also observe a third category. Havlík and Stanley (2015) write that some populist parties are non-ideological because their positions on economy issues and the common GAL/TAN scales are too fuzzy with various mutually inconsistent policy proposals. They therefore refer to these parties as centrist populist. We take an empirical approach to this matter and add this third category when assigning parties the label of left-wing and right-wing parties in our operationalization. It allows us to avoid categorizing parties as left or right when their proposals are too incoherent. We return to this point in our research strategy section.
} 
of systemic exclusion of groups considered minorities from exercising central power or other political rights (Merkel et al., 2016).

Here, we expect the populist element to interact with the host ideology. As written above, left-wing populist parties typically consider ethnic minorities as part of the people and hence, demand equal rights as part of their socially egalitarian tradition. In Europe as in Latin America, left-wing populist parties tend to be inclusive. In contrast, right-wing populist parties tend to be exclusive (Mudde \& Rovira Kaltwasser, 2013), particularly in government where they have a lower incentive to reach out to minorities as part of a vote-maximizing campaign strategy. March (2011, p. 134), for example, shows that the left-wing Scottish Socialist Party (SSP) and the allied Respect coalition raised awareness about the Muslim population in the United Kingdom and initiated a pro-Muslim discourse. In contrast, the Slovak National Party (SNS) routinely targeted Hungarian minority parties and went as far as to propose a ban of all ethnic parties in Slovakia (Koev, 2015, p. 652).

H1. The presence of left-wing populist parties is positively associated with minority rights, whereas the presence of right-wing populist parties relates negatively to minority rights.

\subsection{Mutual Constraints}

Mutual constraints inhibit absolute power in a democracy by balancing the power of the executive vis-à-vis the judiciary and the legislature (Plattner, 2010).

In contrast to minority rights, where the host ideology is central, we argue that in the case of mutual constraints, the populist element determines the direction of the relationship. The strong focus of populist parties on the people can delegitimize the indirect aggregation of the volonté générale via the representative system. On the one hand, populist parties demand either stronger or more frequently employed measures of direct democracy to ease the implementation of the general will. On the other hand, if populist parties enter government, they see no need for a check on power, as they represent the peoples' will (Mudde \& Rovira Kaltwasser, 2012). One such example is the attempt by the Polish Law and Justice Party (PiS), which assumed governmental power in 2015, to reform the Polish Supreme Court. Among the proposed changes, was the suggestion that judges would be appointed by the National Council of the Judiciary in which half the members would also be members of the parliament, effectively weakening the court's power to oversee political decisions (Walsh, 2017). And although the law was partially rejected by Poland's President Andrzej Duda at first, Poland's Premier Beata Szydlo (PiS) in reaction to the rejection said that, just like the parliament, the court should be under the control of the people (Waldoch, Krajweski, \& Bartyzel, 2017).

This association does not depend upon the host ideology. Most populist parties regularly call for changes to the constitution to empower the executive. Parties on the left, such as Fico's Smer in Slovakia (Malová \& Učeň, 2010), have voiced similar demands to those on the right, for example, Haider's Austrian Freedom Party (Austrian Freedom Party, 2011; Fallend, 2012) and the Czech Rally for the Republic/Republican Party of Czechoslovakia (Hanley, 2012). Each of them has demanded more power for the ruling executive to shift power away from parliaments and courts. Since the volonté générale is the rationale for decisions made and actions were taken by all populist parties here, we expect no differences among them regarding their influence on mutual constraints.

H2. The presence of populist parties is negatively associated with mutual constraints, regardless of the parties' host ideology.

\section{Research Strategy}

To test our theoretical arguments, we use a twofold strategy. First, we assess the differences between populist parties in government and opposition. Second, we distinguish between left-wing, center and right-wing populism to investigate the expected associations with minority rights and mutual constraints.

Empirically, we use a pooled cross-sectional design. Since we use the role within a political system as well as a party's host ideology, we opted for cabinets as the temporal unit of analysis. This approach allows us to determine whether a party is in government or opposition with great precision, while other approaches such as country-years are considerably more imprecise. Our data includes information from 30 European countries between 1990 and 2012. ${ }^{6}$ This time span captures major events for European populist parties, from their establishment through their rise. We exclude cabinets with duration of fewer than six months as we assume that any measurable impact is only evident after some time.

\subsection{Dependent Variable}

To measure democratic quality based on our concept of liberal democracy, we draw on three different sources. We measure aggregated liberal democratic quality by using the liberal democracy score (v2x_libdem) of the Varieties of Democracy Project (Coppedge et al., 2011). ${ }^{7}$ To capture the two subdimensions, mutual constraints, and minority rights, we rely on the Democracy Barometer. For mutual constraints, we use the aggregated di-

\footnotetext{
${ }^{6}$ We chose 2012 as our cut-off point as data for most of our most dependent variables was not available beyond that year at the time of the data collection. For an overview of all countries included, see Table A1 in the Appendix A.

${ }^{7}$ In order to ease presentation, we multiplied the v2x_libdem by 100 . This makes the results comparable to the Democracy Barometer which usually applies scales ranging from 0 to 100 .
} 
mension of horizontal checks (MC_CHECKS, Merkel et al., 2016 , p. 29) which measures the balance between executive and legislative (ratio of parliamentary seats controlled by government to parliamentary seats controlled by opposition), the balance of checks between executive and legislative (ratio of control instruments of legislative over executive to control instruments of executive over legislative), and the power of judicial branch to review political decisions. ${ }^{8}$ This measure taps into the checksand-balances aspect. For minority rights, we use an indicator for the effective access to power for minorities (REP_DR3, Merkel et al., 2016, p. 53) that measures the descriptive representation of minorities and the extent to which they have access to central power.

\subsection{Independent Variables}

For testing our hypotheses, we use dummies to i) capture the presence of populist parties in opposition and government and ii) to capture either the presence of left-wing or right-wing populist parties. We further use a middle category for ambivalent cases that would not fit either of the right- or left-wing categories based on our coding procedure, which followed a three-step approach. First, we surveyed the existing secondary literature on populist parties in Europe to categorize parties in populist and non-populist parties. ${ }^{9}$ In the next step, we determined the role of populist parties in the political system, applying the following coding scheme: populist parties in government had to hold some position in the cabinet and populist parties in opposition had to hold at least one seat in the national parliament. Thus, we excluded parties identified as populist but without a seat in parliament during the relevant cabinet from our analyses. Table A1 in Appendix A lists all parties analyzed.

Finally, to determine whether a populist party belongs to one of our three categories (left, right, center), we code populist parties in relation to their countryspecific party system. The procedure is the following. First, we calculate a weighted party system's ideology mean for each cabinet. This average takes into consideration the ideological positions of all parliamentary parties in one particular country. We use the seat share of the respective parties to weight the mean. For each cabinet, we then classify populist parties as left, right, or center according to their relative distance to this weighted mean. We code every populist party within one weighted standard deviation of this reference as centrist, while parties further to the left or right are coded respectively (also see Huber \& Ruth, 2017). ${ }^{10}$

\subsection{Control Variables}

In addition to our central variables, we include a selected set of covariates that, in theory, may relate to both the presence of populist parties as well as the levels of our democratic measures. These variables are the level of democratic consolidation (time in years since democratization), cabinet duration (in years), cabinet composition (surplus governments, minimal winning coalitions, and minority governments), economic development (GDP per Capita in 1,000 US Dollar), and a dichotomous variable to distinguish between post-communist countries and other countries. A detailed rationale for the inclusion of these variables can be found in Appendix $C$.

\subsection{Empirical Model}

To control for country-specific effects, we apply a linear mixed-effects model with cabinets nested under each country (Gelman \& Hill, 2007). ${ }^{11}$ The respective countries serve as groups. This particular model also allows us to compare both intra- and cross-country variance. Given our interest in the change in democratic quality as a consequence of the presence of populist parties, modeling intra-country variance allows us to approximate this process. $^{12}$

\section{Empirical Results}

In Figure 1, we plot the coefficients from the results. ${ }^{13}$

To start with the aggregate measure of liberal democracy (left panel in Figure 1), we observe that in Europe, there is no general association between populist parties and democracy, independent of their status (government or opposition). While we find the anticipated direction of correlation, that is negative for populists in government and positive for those actors in opposition, they are not statistically significant. However, a different picture emerges when distinguishing populist parties according to their host ideology. First, we see that rightwing populist parties are associated with lower levels of

\footnotetext{
${ }^{8}$ An extension of this instrument also measures vertical checks, i.e. the degree of federalism and subnational fiscal autonomy. We did not include these in our central analyses given the focus on political contestation and power checks. However, we did include them in a robust check (see Appendix B). The substantial results are robust.

${ }^{9}$ We base our case selection on Mudde (2007), Arter (2010), March (2011) and Van Kessel (2015), all of whom rely to a great extent on the Mudde (2004) definition of populism we have adopted here. Following these authors, we also considered changes in a party's level of populism. For example, the Panhellenic Socialist Movement (PASOK) was considered populist prior to Simitis becoming the party's leader in 1996 (March, 2011 ). However, thereafter it took a different course. PASOK was thus only coded as populist up until 1996.

10 We illustrate this, using the Austrian Freedom Party (FPÖ) in Austria. Since Haider took over the party in 1986, the FPÖ has been classified as populist (see Mudde, 2007). They held a position in government in the cabinet Schuessel I (February 4, 2000-February 28, 2003), and for this period, were coded as "populist in government". In a next step, we calculate the party systems mean for the period of the cabinet, which is 5.7 on a ten-point scale for Schuessel I. All parties within one standard deviation of the mean (2.1 [3.6 to 7.8]) are coded as central. Because the FPÖ was coded as 8.3 by ParlGov, it is coded as "right-wing populist in government" for the cabinet period of Schuessel I.

${ }^{11}$ A comparison between Null and Empty model (see Table A3 in Appendix A) suggests using hierarchical models.

12 Table A2 in Appendix A shows descriptive statistics for all variables.

13 For the full regression output in table format, see Tables B2 and B3 in Appendix B.
} 


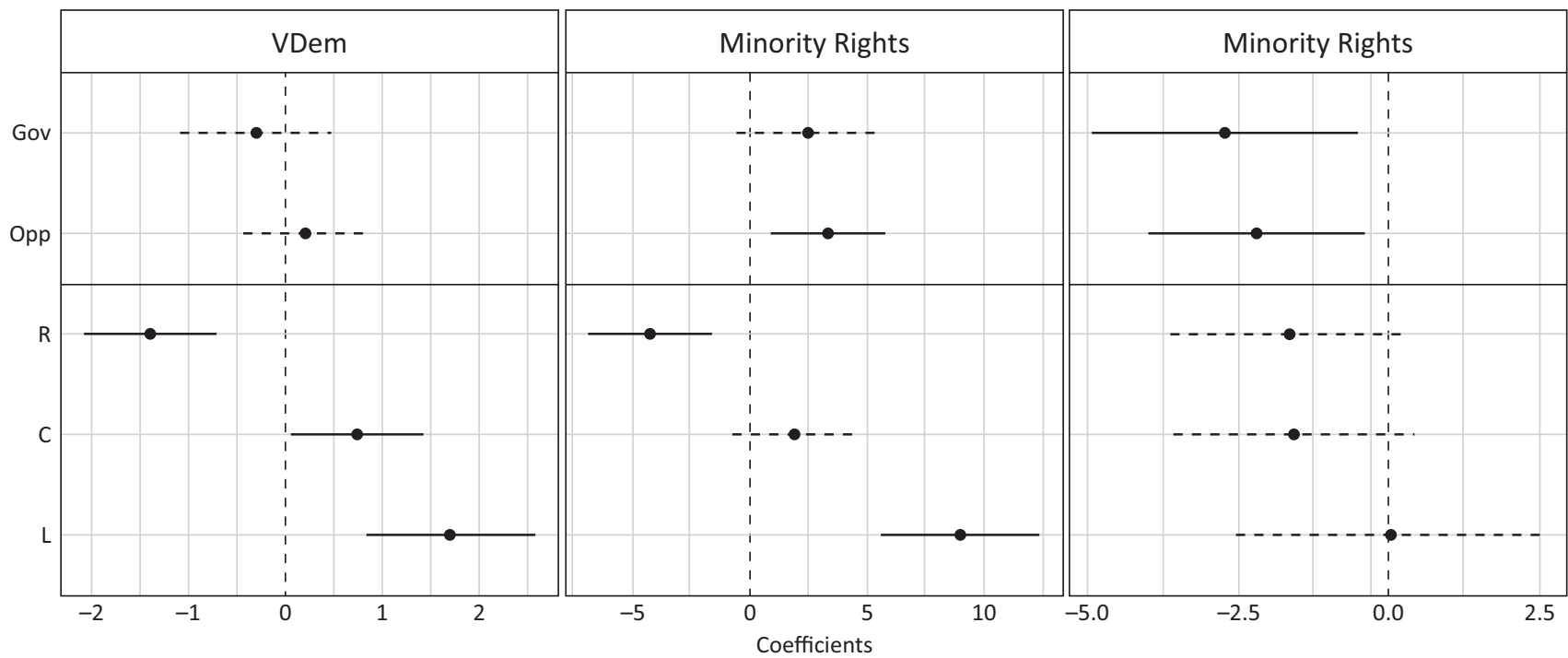

Figure 1. Effect of Populism on Liberal Democracy and two Subdimensions (Minority Rights and Mutual Constraints). Notes: Gov = Populist Party in Government (Reference: No Populist Party in Government); Opp = Populist Party in Opposition (Reference: No Populist Party in Opposition); R = Right-Wing Populist Party present (Reference: No Right-Wing Populist Party present); $C=$ Centrist Populist Party present (Reference: No Centrist Populist Party present); $L=$ Left-Wing Populist Party present (Reference: No Left-Wing Populist Party present); Coefficients are plotted with $90 \%$ Confidence Intervals

quality of liberal democracy. Second, both center and left-wing populist parties are associated with higher levels of quality of liberal democracy. Third, while the center and left-wing populist parties are statistically different from right-wing populist parties, there is no significant difference between those two categories. These findings provide a first idea about potential differences in the association between populist parties and liberal democracy as a consequence of varying host ideologies. For a detailed look, we now turn to the results from the two subdimensions, minority rights, and mutual constraints.

From the middle panel in Figure 1, we can first observe that populist parties in government are not associated with any particular direction regarding minority rights. In contrast, populist parties in opposition are associated with a positive development. Upon taking into consideration host ideology, however, we find that this does not apply to all populists equally. For minority rights, we expected a more negative effect of rightwing populist parties and a positive influence of left-wing populist parties, both in comparison to the absence of populist parties. The empirical results lend support to our argument. First, on average we observe a substantial positive relationship between left-wing populist parties and minority rights, whereas we find negative effects for right-wing populist parties. The presence of centrist populist parties is neither negatively nor positively correlated with minority rights.
For mutual constraints, we expected no differences between the different type of populist parties but on average, small negative associations for all of them. Figure 1 confirms these expectations. We observe no systematic effect of a populist parties' host ideology. However, populist parties in government and opposition are negatively associated with mutual constraints compared to instances where no populist parties are in government or opposition. This effect is in line with our expectation that populists undermine the separation of power. ${ }^{14}$

We conducted two types of robustness checks. First, we reran our analysis using a continuous variable that measures the logged seat share of populist parties instead of dummies (See Tables B9 and B10 in the Appendix). ${ }^{15}$ Second, we used alternative model specifications (lagged dependent variable models - See Tables B5, B6 and B7 in the Appendix). ${ }^{16}$ The most consistent finding across these additional checks is the positive association between left-wing populist parties and minority rights in comparison to right-wing populist parties, particularly in opposition. ${ }^{17}$ Other findings, such as populist parties' relationship with mutual constraints, are less consistent as they are met with greater uncertainty in our statistical models. Overall, these findings further support our idea that substantive differences in the relationship between populist parties can arise from host ideologies.

\footnotetext{
14 Figure B2 in Appendix B includes all combinations of host ideology and government status, which leaves us with six dummies. Substantially, it confirms the findings of Figure 1.

${ }^{15}$ As a logarithm of zero (" 0 ") is not possible, we added 1 to all values to guarantee numeric values, which are necessary to process the data.

16 Results for these and further robustness checks can be found in Appendix B (Figures B3 and B4, Tables B5, B6, B7, B8, B9 and B10).

17 We also ran a third analysis in which we coded parties that were not formally part of a government but supported government parties in parliamentary elections as "populist parties in government". This was the case for the Danish People's Party (2001-2011) and the Dutch Freedom Party (2010-2012). These results are also included in the Appendix B (Table B8).
} 


\section{Discussion and Conclusion}

Populist parties, because of their central ideas of antielitism, the belief in a general will, and their people centrism, challenge some of the commonly accepted rules of democracy, especially those of liberal democracy (Plattner, 2010). However, a series of studies have identified not only negative but also positive effects of populist parties on democratic quality (Canovan, 1999; Mudde \& Rovira Kaltwasser, 2012). Largely absent from the debate surrounding populism and its relationship to democracy, however, has been the role of host ideologies. This article sought to initiate such discussion. We proposed that the host ideology, focusing on left- and right-wing populism, has consequences for how these parties relate to the dimension of political inclusion and minority rights in particular. However, we expected the host ideology to be irrelevant for a populist parties' association with mutual constraints. The empirical findings lend support in particular to the first of our propositions. The main takeaway from our article, therefore, is that populism should not be examined in isolation from its host ideology when considering the relationship between populist actors and democracy. This finding, of course, should not diminish the role populism plays in this relationship, particularly in the wake of temporary developments in cases such as Poland and Hungary. In some cases, however, populism may matter less or even only constitute as an additional qualifier of radical right parties rather than being a steady feature (cf. Rydgren, 2017). Future studies thus could explore under which conditions ideology and populism may play a greater role for populist parties and how they relate to specific aspects of democracy, an issue in which fundamental differences in historical legacies between East- and West-Europe may well play into (Gherghina \& Soare, 2013). Furthermore, right-wing populist parties have been shown to mobilize certain voter groups which have been neglected by other political parties, such as citizens who are lower educated or poor (e.g., Huber \& Ruth, 2017; Rooduijn, 2017). At the same time, they may also discourage certain voters from turning out in elections (Immerzeel \& Pickup, 2015). Future research, by focusing on the dimension of political participation, may therefore also explore whether left-wing populist parties exert similar effects or, whether mobilization and de-mobilization effects depend on a populist party's host ideology.

\section{Acknowledgements}

The authors are grateful to Jessica Fortin-Rittberger, Reinhard Heinisch, Nicole V. T. Lugosi, Liam F. McGrath, Stephen Quinlan, Saskia P. Ruth, Svend-Erik Skaaning, Steven M. Van Hauwaert, Markus Wagner, the editors of the journal, the editors of the thematic issue, and the three anonymous reviewers for their helpful comments. We presented earlier versions of this article at the Annual Austrian Political Science Conference (Salzburg, Novem- ber 2015), and the European Political Science Association (EPSA) Annual Conference (Brussels, June 2016) and want to thank all participants of the panels for their valuable input. Christian H. Schimpf acknowledges the support by the GESIS Leibniz Institute for the Social Sciences and the University of Mannheim's Graduate School of Economic and Social Sciences funded by the German Research Foundation. All mistakes remain ours.

\section{Conflict of Interests}

The authors declare no conflict of interests.

\section{References}

Abts, K., \& Rummens, S. (2007). Populism versus democracy. Political Studies, 55(2), 405-424.

Albertazzi, D., \& Mueller, S. (2013). Populism and liberal democracy: Populists in government in Austria, Italy, Poland and Switzerland. Government and Opposition, 48(3), 343-371.

Arter, D. (2010). The breakthrough of another West European populist radical right party? The case of the True Finns. Government and Opposition, 45(4), 484-504.

Aslanidis, P. (2016). Is populism an ideology? A refutation and a new perspective. Political Studies, 61(1), 88-104.

Aslanidis, P. (2017). Avoiding bias in the study of populism. Chinese Political Science Review, 2(3), 266-287.

Austrian Freedom Party. (2011). Party programme of the Freedom Party of Austria (FPÖ)-Austria first. Graz: FPÖ.

Batory, A. (2016). Populists in government? Hungary's "System of national cooperation". Democratization, 23(2), 283-303.

Beetham, D. (2004). Towards a universal framework for democracy assessment. Democratization, 11(2), 1-17.

Canovan, M. (1999). Trust the people! Populism and the two faces of democracy. Political Studies, 47(1), 2-16.

Caramani, D. (2017). Will vs. reason: The populist and technocratic forms of political representation and their critique of party government. American Political Science Review, 111(1), 54-67.

Coppedge, M., Gerring, J., Altman, D., Bernhard, M., Fish, S., Hicken, A., . . . Teorell, J. (2011). Conceptualizing and measuring democracy: A new approach. Perspectives on Politics, 9(2), 247-267.

Dahl, R. A. (1971). Polyarchy: Participation and opposition. New Haven, CT: Yale University Press.

De Lange, S. L., \& Akkerman, T. (2012). Populist parties in Belgium: A case of hegemonic liberal democracy? In C. Mudde \& C. Rovira Kaltwasser (Eds.), Populism in Europe and the Americas (pp. 27-46). Cambridge: Cambridge University Press.

Diamond, L. J., \& Morlino, L. (2005). Assessing the quality of democracy. Baltimore, MD: Johns Hopkins University Press. 
Fallend, F. (2012). Populism in government: The case of Austria (2000-2007). In C. Mudde \& C. Rovira Kaltwasser (Eds.), Populism in Europe and the Americas (pp. 113-136). Cambridge: Cambridge University Press.

Gelman, A., \& Hill, J. (2007). Data analysis using regression and multilevel/hierarchical models. Cambridge and New York, NY: Cambridge University Press.

Gherghina, S., \& Soare, S. (2013). Introduction: Populism-A sophisticated concept and diverse political realities. In S. Gherghina, S. Miscoiu, \& S. Soare (Eds.), Contemporary populism: A controversial concept and its diverse forms (pp. 1-15). Newcastle: Cambridge Scholars Publishing.

Hanley, S. (2012). The Czech Republicans 1990-1998: A populist outsider in a consolidating democracy. In C. Mudde \& C. Rovira Kaltwasser (Eds.), Populism in Europe and the Americas (pp. 68-88). Cambridge: Cambridge University Press.

Havlík, V., \& Stanley, B. (2015). New populist parties in Central and Eastern Europe: Non-ideological or centrist? Paper presented at the Team Populism Conference "Solving the Puzzles of Populism", London, UK.

Hawkins, K. A. (2009). Is Chávez populist? Measuring populist discourse in comparative perspective. Comparative Political Studies, 42(8), 1040-1067.

Hawkins, K. A. (2010). Venezuela's Chavismo and populism in comparative perspective. New York, NY: Cambridge University Press.

Houle, C., \& Kenny, P. D. (2016). The political and economic consequences of populist rule in Latin America. Government and Opposition. doi:10.1017/ gov.2016.25

Huber, R. A., \& Schimpf, C. H. (2016a). A drunken guest in Europe? The influence of populist radical right parties on democratic quality. Zeitschrift Für Vergleichende Politikwissenschaft, 10(2), 103-129.

Huber, R. A., \& Schimpf, C. H. (2016b). Friend or foe? Testing the influence of populism on democratic quality in Latin America: Friend or foe? Populism and democracy. Political Studies, 64(4), 872-889.

Huber, R. A., \& Schimpf, C. H. (2017). Populism and democracy-Theoretical and empirical considerations. In R. C. Heinisch, C. Holtz-Bacha, \& O. Mazzoleni (Eds.), Handbook on political populism (pp. 329-344). Baden-Baden: Nomos.

Huber, R. A., \& Ruth, S. P. (2017). Mind the gap! Populism, representation, and participation in Europe. Swiss Political Science Review. doi:10.1111/spsr. 12280

Immerzeel, T., \& Pickup, M. (2015). Populist radical right parties mobilizing 'the people'? The role of populist radical right success in voter turnout. Electoral Studies, 40, 347-360.

Jagers, J., \& Walgrave, S. (2007). Populism as political communication style: An empirical study of political parties' discourse in Belgium. European Journal of Political Research, 46(3), 319-345.
Katsambekis, G. (2017). The populist surge in postdemocratic times: Theoretical and political challenger. The Political Quarterly, 88(2), 202-210.

Koev, D. (2015). Interactive party effects on electoral performance: How ethnic minority parties aid the populist right in Central and Eastern Europe. Party Politics, 21(4), 649-659.

Kriesi, H. (2014). The populist challenge. West European Politics, 37(2), 361-378.

Malová, D., \& Učeň, P. (2010). Slovakia. European Journal of Political Research, 49(7/8), 1154-1162.

March, L. (2011). Radical left parties in contemporary Europe. Abingdon: Routledge.

Markowski, R. (2016). The Polish parliamentary election of 2015: A free and fair election that results in unfair political consequences. West European Politics, 39(6), 1311-1322.

Mény, Y., \& Surel, Y. (Eds.). (2002). Democracies and the populist challenge. New York, NY: Palgrave.

Merkel, W., Bochsler, D., Bousbah, K., Bühlmann, M., Giebler, H., Hänni, M., . . W Weßels, B. (2016). Democracy barometer: Methodology: Version 5. Aarau: Zentrum für Demokratie.

Mudde, C. (2004). The populist zeitgeist. Government and Opposition, 39(4), 542-563.

Mudde, C. (2007). Populist radical right parties in Europe. Cambridge and New York, NY: Cambridge University Press.

Mudde, C., \& Rovira Kaltwasser, C. (Eds.). (2012). Populism in Europe and the Americas: Threat or corrective for democracy? Cambridge: Cambridge University Press.

Mudde, C., \& Rovira Kaltwasser, C. (2013). Exclusionary vs. inclusionary populism: Comparing contemporary Europe and Latin America. Government and Opposition, 48(2), 147-174.

Müller, J.-W. (2016). What is populism? Philadelphia, PA: University of Pennsylvania Press.

Müller, W. C. (2002). Evil or the 'engine of democracy'? Populism and party competition in Austria. In Y. Mény \& Y. Surel (Eds.), Democracies and the populist challenge (pp. 155-175). New York, NY: Palgrave.

Otjes, S., \& Louwerse, T. (2015). Populists in parliament: Comparing left-wing and right-wing populism in the Netherlands. Political Studies, 63(1), 60-79.

Pappas, T. S. (2014). Populist democracies: Postauthoritarian Greece and post-communist Hungary. Government and Opposition, 49(1), 1-23.

Pappas, T. S. (2016). The specter haunting Europe: Distinguishing liberal democracy's challengers. Journal of Democracy, 27(4), 22-36.

Plattner, M. F. (2010). Populism, pluralism, and liberal democracy. Journal of Democracy, 21(1), 81-92.

Rensmann, L. (2006). Populismus und Ideologie [Populism and ideology]. In F. Decker (Ed.), Populismus [Populism] (pp. 59-80). Wiesbaden: VS Verlag für Sozialwissenschaften.

Rooduijn, M. (2014). The nucleus of populism: In search 
of the lowest common denominator. Government and Opposition, 49(4), 573-599.

Rooduijn, M. (2017). What unites the voter bases of populist parties? Comparing the electorates of 15 populist parties. European Political Science Review. doi:10.1017/S1755773917000145

Rooduijn, M., \& Akkerman, T. (2017). Flank attacks: Populism and left-right radicalism in Western Europe. Party Politics, 23(3), 193-204.

Ruth, S. (2017). Populism and the erosion of horizontal accountability in Latin America. Political Studies. doi:10.1177/0032321717723511

Rydgren, J. (2017). Radical right-wing parties in Europe. What's populism got to do with it? Journal of Language and Politics. doi:10.1075/jlp.17024.ryd

Stanley, B. (2008). The thin ideology of populism. Journal of Political Ideologies, 13(1), 95-110.
Taggart, P. A. (2000). Populism. Buckingham and Philadelphia, PA: Open University Press.

Van Kessel, S. (2015). Populist parties in Europe: Agents of discontent? Houndmills, Basingstoke, Hampshire and New York, NY: Palgrave Macmillan.

Waldoch, M., Krajweski, A., \& Bartyzel, D. (2017). Polish premier vows to push on with court revamp after veto. Bloomberg. Retrieved from https://www. bloomberg.com/news/articles/2017-07-24/polishpremier-vows-to-push-on-with-court-overhaul-aftervetoes

Walsh, A. (2017). What are Poland's judicial reforms proposed by Jaroslaw Kaczynski? DW. Retrieved from http://www.dw.com/en/what-are-polands-judi cial-reforms-proposed-by-jaroslaw-kaczynski/a-3975 4554

\section{About the Authors}
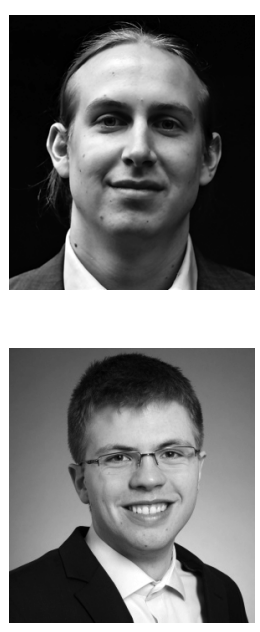

Robert A. Huber is a PhD student in the International Relations group at ETH Zurich, Switzerland. Robert's work focuses on explanations and consequences of populism as well as explanations of climate skepticism and environmental behavior. He published articles in Political Studies and Zeitschrift für Vergleichende Politikwissenschaft.

Christian H. Schimpf is a PhD candidate in political science at the Graduate School of Economics and Social Sciences at the University of Mannheim. He is also a Data Processing Specialist with the Comparative Study of Electoral Systems (CSES) Secretariat at the GESIS Leibniz Institute for the Social Sciences, Mannheim. His research interests include comparative political behavior, populism and public opinion. His research has been published in Political Studies and the Zeitschrift für Vergleichende Politikwissenschaft. 


\section{Appendix}

\section{Appendix A. Descriptive Information}

Table A1. List of populist parties in dataset.

\begin{tabular}{|c|c|c|c|}
\hline $\mathrm{C}$ & Party & Populists & Host Ideology \\
\hline AT & Freedom Party Austria (FPÖ) & since 1986 & $\mathrm{R}$ \\
\hline AT & Alliance for the Future of Austria (BZÖ) & since 2005 & $\mathrm{R}$ \\
\hline BE & Flemish Block (VB) & 1979-2004 & $\mathrm{R}$ \\
\hline $\mathrm{BE}$ & Flemish Interest (VB) & since 2004 & $\mathrm{R}$ \\
\hline BE & National Front (FNb) & 1985-2012 & $\mathrm{R}$ \\
\hline $\mathrm{BE}$ & List Dedecker (LDD) & 2007-2010 & $\mathrm{C}$ \\
\hline BG & Attack (Ataka) & since 2005 & $\mathrm{C}$ \\
\hline BG & Law, Order and Justice (PPS) & 2009-2013 & $\mathrm{R}$ \\
\hline BG & National Movement Simeon the Second (NDSV) & 2001-2005 & $\mathrm{C}$ \\
\hline BG & Citizens for European Development of Bulgaria (GERB) & since 2009 & C (2009) \\
\hline $\mathrm{HR}$ & Croatian Democratic Union (HDZ) & since 1989 & $\mathrm{C}$ \\
\hline $\mathrm{HR}$ & Croatian Party of Rights (HSP) & since 1990 & $\mathrm{R}$ \\
\hline $\mathrm{CH}$ & Swiss Democrats (SD) & since 1961 & $\mathrm{R}$ \\
\hline $\mathrm{CH}$ & Freedom Party of Switzerland (FPS) & since 1984 & $\mathrm{R}$ \\
\hline $\mathrm{CH}$ & Swiss People's Party (SVP) & since 1971 & $\mathrm{R}$ \\
\hline $\mathrm{CH}$ & League of Ticinesians (LdT) & since 1991 & $\mathrm{R}$ \\
\hline $\mathrm{CZ}$ & Rally for the Republic-Republican Party of Czechoslovakia (SPR-RSC) & since 1989 & $\mathrm{R}$ \\
\hline $\mathrm{CZ}$ & Public Affairs (VV) & since 2001 & $\mathrm{C}$ \\
\hline DK & Progress Party (FPd) & since 1972 & $\mathrm{R}$ \\
\hline DK & The Danish People's Party (DFP) & since 1995 & $\mathrm{R}$ \\
\hline $\mathrm{EE}$ & Estonian Citizens (EK) & 1992 & $\mathrm{R}$ \\
\hline $\mathrm{EE}$ & Estonian National Independence Party (ERSP) & 1988-1995 & $\mathrm{C}$ \\
\hline $\mathrm{EE}$ & Estonian United People's Party (EUR) & 1994-2006 & $\mathrm{L}$ \\
\hline $\mathrm{FI}$ & Finnish Rural Party (SMP) & 1959-1995 & $\mathrm{C}$ \\
\hline $\mathrm{FI}$ & Finns Party (PS) & since 1995 & $\mathrm{C}$ \\
\hline FR & National Front (FN) & since 1972 & $\mathrm{R}$ \\
\hline GE & Party for Democratic Socialism (PDS) & 1990-2005 & $\mathrm{L}$ \\
\hline GE & The Left / PDS & $2005-2007$ & $\mathrm{~L}$ \\
\hline GE & The Left & since 2007 & $\mathrm{~L}$ \\
\hline GR & Panhellenic Socialist Movement (PASOK) & until 1996 & $\mathrm{C}$ \\
\hline GR & Popular Orthodox Rally (LAOS) & since 2000 & $\mathrm{R}$ \\
\hline GR & Coalition of the Radical Left (SYRIZA) & since 2004 & $\mathrm{~L}$ \\
\hline GR & Independent Greeks (AE) & since 2012 & $\mathrm{R}$ \\
\hline $\mathrm{HU}$ & Hungarian Justice and Life Party (MIEP) & since 1993 & $\mathrm{R}$ \\
\hline $\mathrm{HU}$ & Alliance of Young Democrats (FIDESZ) & since 2006 & $R(2006), C(2010)$ \\
\hline IR & Sinn Féin (SF) & since 1970 & $\mathrm{~L}$ \\
\hline IT & Lega Nord (LN) & since 1991 & $\begin{array}{l}R(1992,1996,2001,2006, \\
2008), C(1994,1996)\end{array}$ \\
\hline IT & Come on Italy/ People of Freedom Party (FI-PdL) & 1995-2009 & $\mathrm{C}$ \\
\hline LV & For Fatherland and Freedom (LNNK) & 1993-2001 & $\mathrm{C}$ \\
\hline $\mathrm{LI}$ & Young Lithuania (JL) & since 1994 & $\mathrm{R}$ \\
\hline $\mathrm{LI}$ & Order and Justice (TT) & since 2002 & $\mathrm{C}$ \\
\hline $\mathrm{LI}$ & Labour Party (DP) & since 2003 & C (2004), L (2008) \\
\hline LU & Alternative Democratic Reform (AR|ADR) & since 2004 & $\mathrm{R}$ \\
\hline $\mathrm{NL}$ & Party for Freedom (PVV) & since 2006 & $\mathrm{R}$ \\
\hline $\mathrm{NL}$ & Socialist Party (SP) & Until 2008 & $\mathrm{~L}$ \\
\hline $\mathrm{NL}$ & The List Pim Fortuyn (LPF) & 2002-2006 & $\mathrm{R}$ \\
\hline $\mathrm{NL}$ & Liveable Netherlands (LN) & 2002-2003 & $\mathrm{R}$ \\
\hline NO & Progress Party (FrP) & since 1973 & $\mathrm{R}$ \\
\hline $\mathrm{PL}$ & Law and Justice (Pis) & since 2001 & C $(2005,2007), R(2011)$ \\
\hline $\mathrm{PL}$ & League of Polish Families (LPR) & since 2001 & $\mathrm{R}$ \\
\hline
\end{tabular}


Table A1. List of populist parties in dataset. (Cont.)

\begin{tabular}{llll}
\hline C & Party & Populists & Host Ideology \\
\hline PL & Self-Defense of the Republic Poland (SRP) & since 1992 & C (2001), L(2005) \\
RO & Greater Romania Party (PRM) & since 1991 & R \\
RO & Romanian National Unity Party (PUNR) & $1990-2006$ & C \\
RO & Party of Social Democracy in Romania (PDSR) & $1993-2001$ & L (1992, 1996), C (2000) \\
RO & People's Party-Dan Diaconescu (PP-DD) & $2011-2015$ & $\mathrm{~L}$ \\
SK & Slovak National Party (SNS) & since 1989 & C (1990, 1998, 2002, 2006, \\
& & & 2010), R (1992, 1994) \\
SK & Party of Civic Understanding (SOP) & $1998-2003$ & $\mathrm{~L}$ \\
SK & Smer (Direction), the Third Way & $1999-2005$ & $\mathrm{~L}$ \\
SK & Smer (Direction), Social Democracy & since 2005 & $\mathrm{L}(2006,2010), \mathrm{C}(2012)$ \\
SK & Movement for a Democratic Slovakia (HZDS) & $2002-2012$ & $\mathrm{C}$ \\
SK & Ordinary People and Independent Personalities Party (OLaNO) & since 2011 & $\mathrm{R}$ \\
SL & Slovenian National Party (SNS) & since 1991 & $\mathrm{C}$ \\
SE & New Democracy (NyD) & $1991-2000$ & $\mathrm{R}$ \\
SE & Sweden Democrats (SD) & since 1988 & $\mathrm{R}$ \\
UK & Sinn Féin (SF) & $1905-$ today & L \\
\hline
\end{tabular}

Note: Sources for these parties are Mudde (2007), Arter (2010), March (2011) and Van Kessel (2015). We should note that the Progress Party (FPd) in Demark and the Swedish party New Democracy (NyD) are borderline cases for that they may fit the category of neoliberal populist parties better. This is the case, as Mudde $(2007$, p. 48) writes, because "their xenophobic rhetoric is primarily informed by their liberalism". We kept these parties in our analyses nonetheless as a) they still fit the category of populist parties and b) would only be relevant for the analyses of minority rights in which case our results are more conservative given the inclusion of two cases that do not share the strong focus on nativism with other cases included here.

Table A2. Descriptive statistics.

\begin{tabular}{|c|c|c|c|c|c|}
\hline Statistic & $\mathrm{N}$ & Mean & St. Dev. & Min & Max \\
\hline Liberal Democracy (VDem) & 255 & 78.56 & 9.83 & 37.32 & 90.36 \\
\hline Liberal Democracy (UDS) & 265 & 1.34 & 0.45 & 0.10 & 2.25 \\
\hline Liberal Democracy (DB) & 255 & 56.44 & 7.53 & 39.60 & 74.48 \\
\hline Minority Rights & 270 & 61.94 & 31.00 & -5.56 & 100.00 \\
\hline Mutual Constraints & 269 & 70.00 & 12.73 & 39.72 & 93.99 \\
\hline Robustness Check: Mutual Constraints & 259 & 46.45 & 9.42 & 28.15 & 75.41 \\
\hline Government & 270 & 0.13 & 0.34 & 0 & 1 \\
\hline Opposition & 270 & 0.53 & 0.50 & 0 & 1 \\
\hline Right & 270 & 0.35 & 0.48 & 0 & 1 \\
\hline Center & 270 & 0.24 & 0.43 & 0 & 1 \\
\hline Left & 270 & 0.14 & 0.35 & 0 & 1 \\
\hline Right Government & 270 & 0.05 & 0.22 & 0 & 1 \\
\hline Right Opposition & 270 & 0.32 & 0.47 & 0 & 1 \\
\hline Center Government & 270 & 0.08 & 0.27 & 0 & 1 \\
\hline Center Opposition & 270 & 0.17 & 0.38 & 0 & 1 \\
\hline Left Government & 270 & 0.02 & 0.15 & 0 & 1 \\
\hline Left Opposition & 270 & 0.12 & 0.33 & 0 & 1 \\
\hline Democratic Consolidation & 263 & 32.95 & 32.47 & 0 & 161 \\
\hline Cabinet Duration & 270 & 26.79 & 15.23 & 6 & 61 \\
\hline Government Type (surplus) & 270 & 0.22 & 0.41 & 0 & 1 \\
\hline Economic Development & 270 & 21.49 & 15.95 & 2.48 & 83.41 \\
\hline Post-Communist Country & 270 & 0.46 & 0.50 & 0 & 1 \\
\hline
\end{tabular}


Table A3. Comparison of empty and null model using VDem.

\begin{tabular}{llllll}
\hline Model & AIC & BIC & logLik & L.Ratio & p-value \\
\hline Null & 1891.3 & 1898.4 & -943.6 & & \\
Empty & 1362.2 & 1372.8 & -678.1 & 531.1 & $<.0001$ \\
\hline
\end{tabular}

\section{Appendix B. Additional Regression Figures and Tables and Robustness Checks (RBC)}

The table below provides an overview of all abbreviations used for the various populist party dummies in the Appendix included in the models, their meaning (when coded as " 1 "), and the reference category (when coded as " 0 ").

Table B1. Abbreviations of populist party dummies, meaning and reference categories.

\begin{tabular}{lll}
\hline Abbreviation & Meaning & Reference Group \\
\hline Gov & Populist Party in Government & No Populist Party in Government \\
Opp & Populist Party in Opposition & No Populist Party in Opposition \\
R & Right-Wing Populist Party Present & No Right-Wing Populist Party Present \\
C & Centrist Populist Party Present & No Centrist Populist Party Present \\
L & Left-Wing Populist Party Present & No Left-Wing Populist Party Present \\
RG & Right-Wing Populist Party in Government & No Right-Wing Populist Party in Government \\
RO & Right-Wing Populist Party in Opposition & No Right-Wing Populist Party in Opposition \\
CG & Centrist Populist Party in Government & No Centrist Populist Party in Government \\
CO & Centrist Populist Party in Opposition & No Centrist Populist Party in Opposition \\
LG & Left-Wing Populist Party in Government & No Left-Wing Populist Party in Government \\
LO & Left-Wing Populist Party in Opposition & No Left-Wing Populist Party in Opposition \\
\hline
\end{tabular}

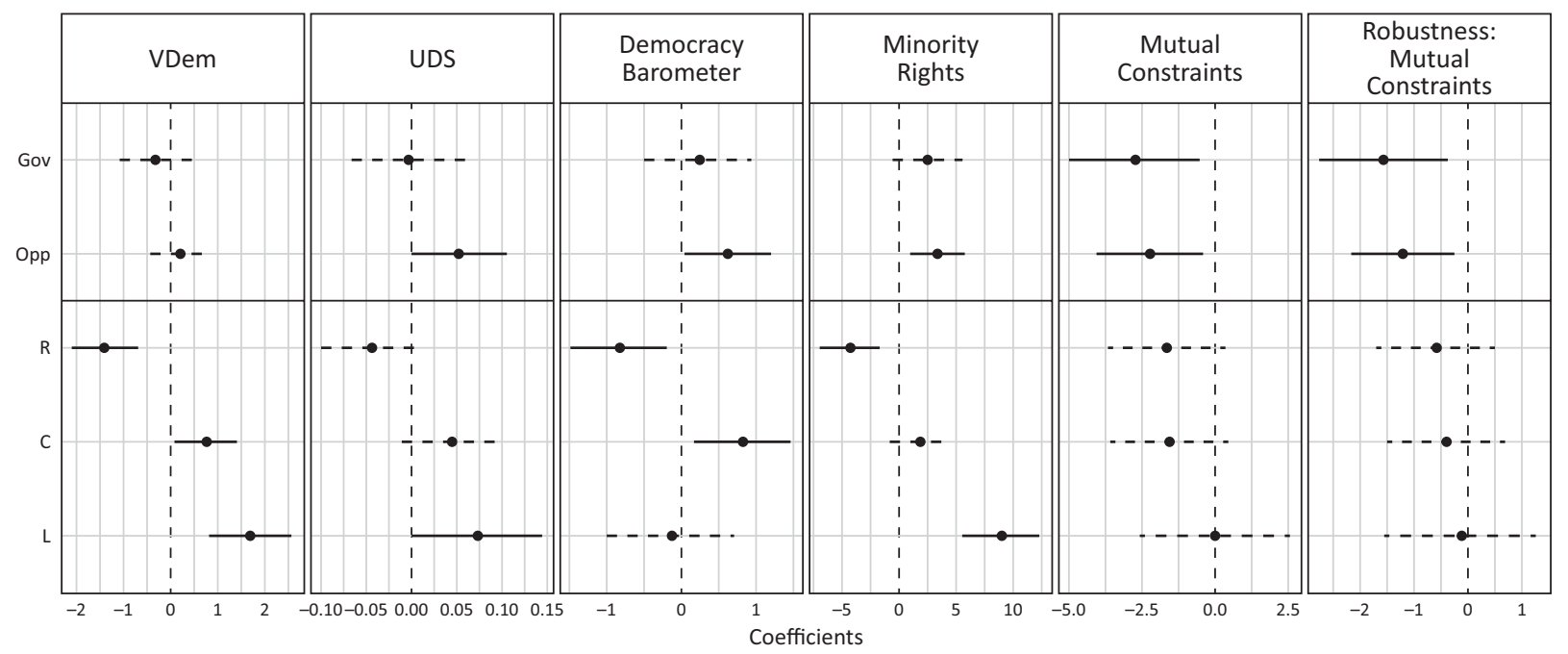

Figure B1. Effect of populism on liberal democracy subdimensions (regression results: Tables B2 and B3). Note: Figure B1 additionally includes two more measures of liberal democracy by the UDS (Pemstein, 2010) and Democracy Barometer (Merkel et al., 2016) 


\section{COGITATIO}

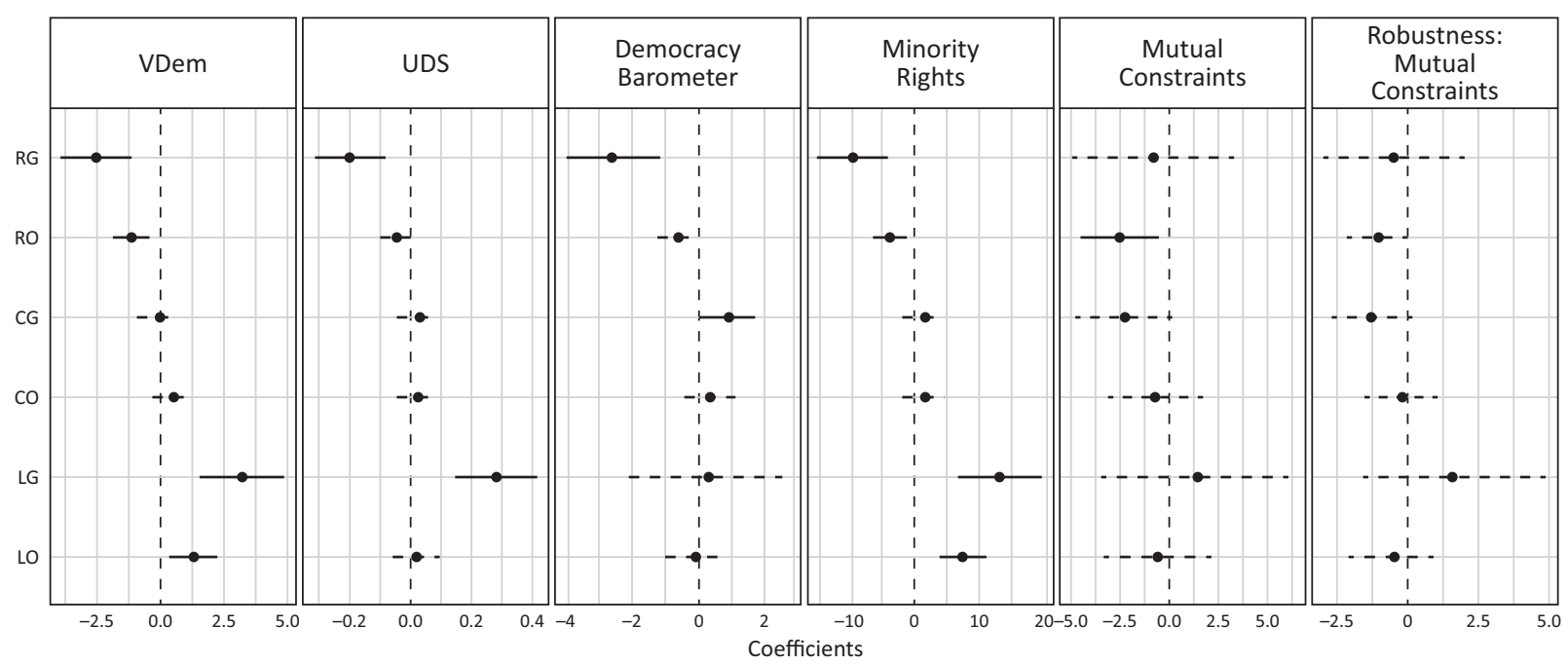

Figure B2. Effect of populism on liberal democracy subdimensions by combinations of host ideology and government status (regression results: Table B4). Note: Figure B2 disentangles combinations of both government status and host ideology.

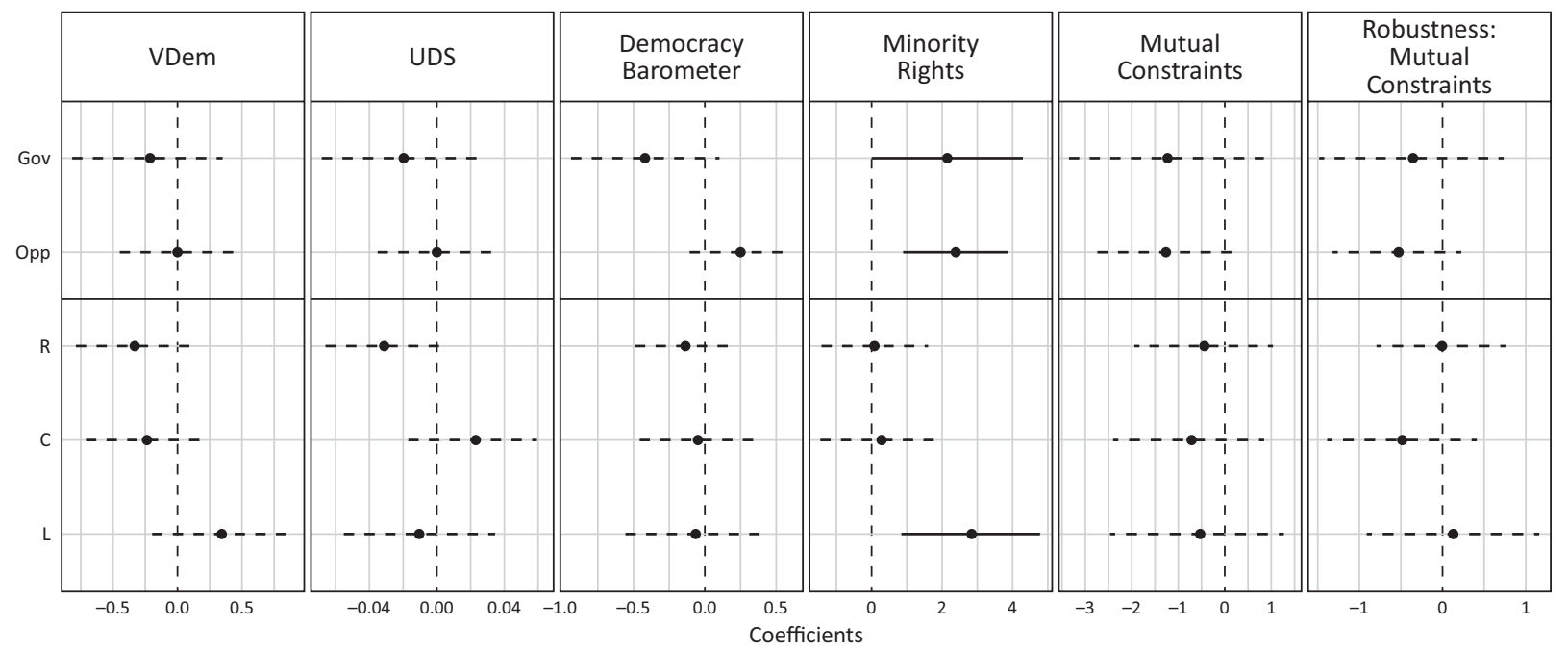

Figure B3. RBC-Effect of populism on liberal democracy subdimensions using a lagged dependent variable (regression results: Tables $\mathrm{B} 5$ and $\mathrm{B} 6$ ).

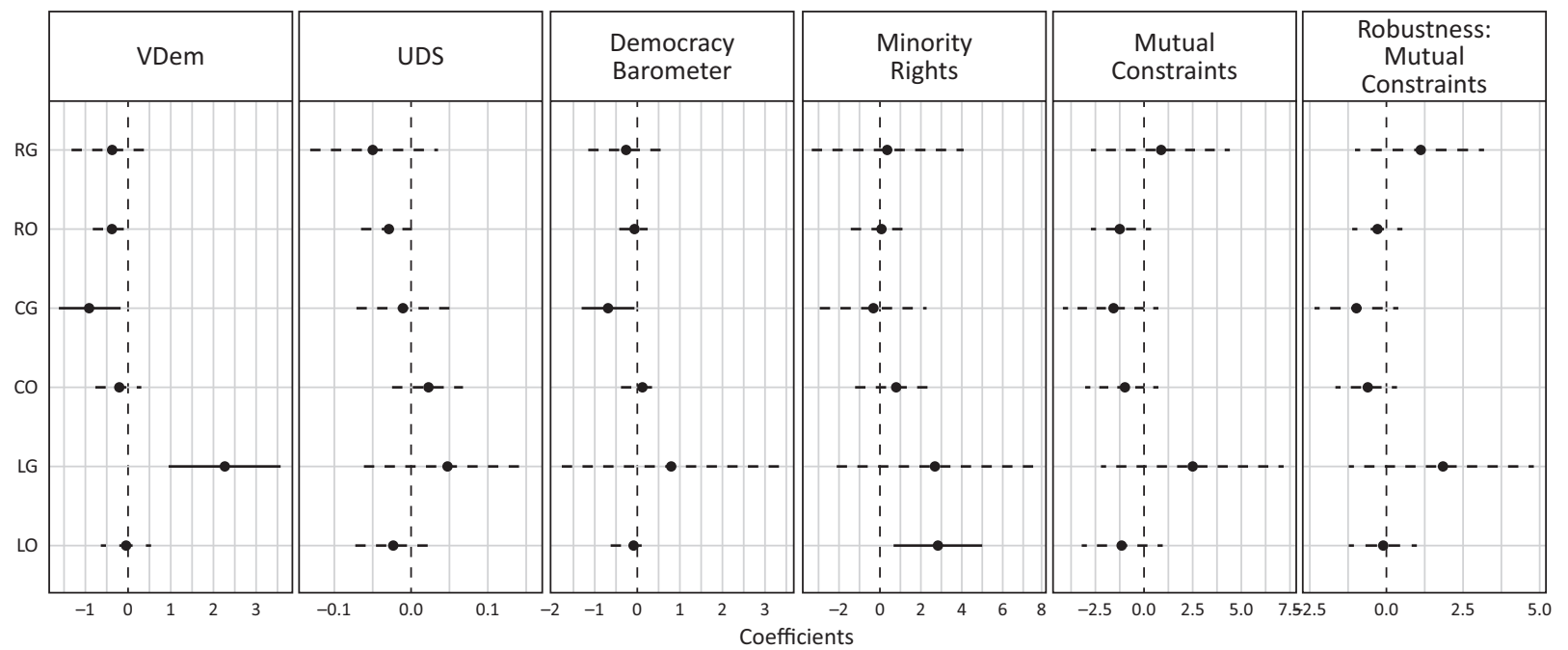

Figure B4. RBC-effect of populism on liberal democracy subdimensions by combinations of host ideology and government status using a lagged dependent variable (regression results: Table B7). 
Table B2. Populism and liberal democracy by government status.

\begin{tabular}{|c|c|c|c|c|c|c|}
\hline & VDem & UDS & DB & $\begin{array}{l}\text { Minority } \\
\text { Rights }\end{array}$ & $\begin{array}{c}\text { Mutual } \\
\text { Constraints }\end{array}$ & $\begin{array}{l}\text { Robustness Check } \\
\text { Mutual Constraints }\end{array}$ \\
\hline \multirow[t]{2}{*}{ Government } & -0.30 & -0.002 & 0.26 & 2.52 & $-2.70 * *$ & $-1.56 * *$ \\
\hline & $(0.48)$ & $(0.04)$ & $(0.45)$ & $(1.85)$ & $(1.34)$ & $(0.73)$ \\
\hline \multirow[t]{2}{*}{ Opposition } & 0.21 & $0.05^{*}$ & $0.62 *$ & $3.39 * *$ & $-2.19 * *$ & $-1.20 * *$ \\
\hline & $(0.39)$ & $(0.03)$ & $(0.35)$ & $(1.51)$ & $(1.10)$ & $(0.59)$ \\
\hline \multirow[t]{2}{*}{ Democratic Consolidation } & $0.19 * * *$ & $0.003^{* *}$ & 0.002 & $0.40 * * *$ & $0.13^{*}$ & $0.18^{* * *}$ \\
\hline & $(0.03)$ & $(0.002)$ & $(0.03)$ & $(0.11)$ & $(0.07)$ & $(0.04)$ \\
\hline \multirow[t]{2}{*}{ Cabinet Duration } & 0.01 & $0.002 *$ & 0.02 & $0.08^{*}$ & 0.04 & 0.02 \\
\hline & $(0.01)$ & $(0.001)$ & $(0.01)$ & $(0.04)$ & $(0.03)$ & $(0.02)$ \\
\hline \multirow[t]{2}{*}{ Government Type (surplus) } & 0.19 & 0.02 & -0.56 & 1.24 & $1.87^{*}$ & $1.61 * * *$ \\
\hline & $(0.40)$ & $(0.03)$ & $(0.36)$ & $(1.56)$ & $(1.13)$ & $(0.60)$ \\
\hline \multirow[t]{2}{*}{ Economic Development } & -0.03 & $0.01 *$ & $0.10 * *$ & -0.30 & -0.05 & -0.06 \\
\hline & $(0.06)$ & $(0.003)$ & $(0.04)$ & (0.19) & $(0.12)$ & $(0.07)$ \\
\hline \multirow[t]{2}{*}{ Post-Communist Country } & 1.50 & $-0.35^{* * *}$ & $-5.65^{* *}$ & $-23.57^{* *}$ & $11.41^{*}$ & 2.39 \\
\hline & (3.59) & $(0.11)$ & $(2.47)$ & $(10.81)$ & $(5.71)$ & $(4.66)$ \\
\hline \multirow[t]{2}{*}{ Constant } & $71.73 * * *$ & $1.21 * * *$ & $55.97 * * *$ & $62.91 * * *$ & $62.22 * * *$ & $41.18^{* * *}$ \\
\hline & $(2.53)$ & $(0.10)$ & (1.74) & (7.77) & $(4.51)$ & $(3.20)$ \\
\hline Observations & 251 & 263 & 251 & 263 & 262 & 255 \\
\hline Log Likelihood & -616.74 & 18.28 & -578.01 & -987.48 & -892.15 & -721.81 \\
\hline AIC & $1,253.49$ & -16.57 & $1,176.02$ & $1,994.96$ & $1,804.30$ & $1,463.62$ \\
\hline $\mathrm{BIC}$ & $1,288.42$ & 18.84 & $1,210.95$ & $2,030.37$ & $1,839.67$ & $1,498.72$ \\
\hline
\end{tabular}

Note: ${ }^{*} \mathrm{p}<0.1{ }^{* *} \mathrm{p}<0.05 ;{ }^{* * *} \mathrm{p}<0.01$.

Table B3. Populism and liberal democracy by host ideology.

\begin{tabular}{|c|c|c|c|c|c|c|}
\hline & VDem & UDS & DB & $\begin{array}{l}\text { Minority } \\
\text { Rights }\end{array}$ & $\begin{array}{c}\text { Mutual } \\
\text { Constraints }\end{array}$ & $\begin{array}{l}\text { Robustness Check } \\
\text { Mutual Constraints }\end{array}$ \\
\hline Right & $\begin{array}{c}-1.39 * * * \\
(0.42)\end{array}$ & $\begin{array}{l}-0.04 \\
(0.03)\end{array}$ & $\begin{array}{c}-0.81 * * \\
(0.39)\end{array}$ & $\begin{array}{c}-4.22 * * * \\
(1.59)\end{array}$ & $\begin{array}{l}-1.63 \\
(1.21)\end{array}$ & $\begin{array}{l}-0.56 \\
(0.69)\end{array}$ \\
\hline Center & $\begin{array}{l}0.75^{*} \\
(0.41)\end{array}$ & $\begin{array}{c}0.05 \\
(0.03)\end{array}$ & $\begin{array}{c}0.82 * * \\
(0.39)\end{array}$ & $\begin{array}{c}1.94 \\
(1.61)\end{array}$ & $\begin{array}{l}-1.55 \\
(1.22)\end{array}$ & $\begin{array}{l}-0.38 \\
(0.67)\end{array}$ \\
\hline Left & $\begin{array}{c}1.71 * * * \\
(0.54)\end{array}$ & $\begin{array}{l}0.07 * \\
(0.04)\end{array}$ & $\begin{array}{l}-0.12 \\
(0.53)\end{array}$ & $\begin{array}{c}8.99 * * * \\
(2.05)\end{array}$ & $\begin{array}{c}0.03 \\
(1.55)\end{array}$ & $\begin{array}{l}-0.11 \\
(0.88)\end{array}$ \\
\hline Democratic Consolidation & $\begin{array}{c}0.19 * * * \\
(0.03)\end{array}$ & $\begin{array}{c}0.003^{* *} \\
(0.002)\end{array}$ & $\begin{array}{l}0.003 \\
(0.03)\end{array}$ & $\begin{array}{c}0.42 * * * \\
(0.11)\end{array}$ & $\begin{array}{l}0.14^{*} \\
(0.07)\end{array}$ & $\begin{array}{c}0.17 * * * \\
(0.05)\end{array}$ \\
\hline Cabinet Duration & $\begin{array}{c}0.01 \\
(0.01)\end{array}$ & $\begin{array}{c}0.001 \\
(0.001)\end{array}$ & $\begin{array}{c}0.01 \\
(0.01)\end{array}$ & $\begin{array}{c}0.08^{* *} \\
(0.04)\end{array}$ & $\begin{array}{c}0.03 \\
(0.03)\end{array}$ & $\begin{array}{c}0.01 \\
(0.02)\end{array}$ \\
\hline Government Type (surplus) & $\begin{array}{l}-0.16 \\
(0.39)\end{array}$ & $\begin{array}{l}0.002 \\
(0.03)\end{array}$ & $\begin{array}{c}-0.69 * \\
(0.36)\end{array}$ & $\begin{array}{c}0.37 \\
(1.51)\end{array}$ & $\begin{array}{c}1.67 \\
(1.15)\end{array}$ & $\begin{array}{c}1.47^{* *} \\
(0.62)\end{array}$ \\
\hline Economic Development & $\begin{array}{l}-0.06 \\
(0.06)\end{array}$ & $\begin{array}{c}0.005 \\
(0.003)\end{array}$ & $\begin{array}{c}0.11 * * * \\
(0.04)\end{array}$ & $\begin{array}{c}-0.39 * * \\
(0.18)\end{array}$ & $\begin{array}{l}-0.06 \\
(0.13)\end{array}$ & $\begin{array}{l}-0.07 \\
(0.07)\end{array}$ \\
\hline Post-Communist Country & $\begin{array}{c}0.68 \\
(3.59)\end{array}$ & $\begin{array}{c}-0.36 * * * \\
(0.12)\end{array}$ & $\begin{array}{c}-5.45^{* *} \\
(2.52)\end{array}$ & $\begin{array}{c}-25.18^{* *} \\
(10.90)\end{array}$ & $\begin{array}{l}11.36 * \\
(5.87)\end{array}$ & $\begin{array}{c}2.03 \\
(4.64)\end{array}$ \\
\hline Constant & $\begin{array}{c}72.91 * * * \\
(2.51)\end{array}$ & $\begin{array}{c}1.24^{* * *} \\
(0.11)\end{array}$ & $\begin{array}{c}56.12 * * * \\
(1.76)\end{array}$ & $\begin{array}{c}66.99 * * * \\
(7.76)\end{array}$ & $\begin{array}{c}61.94 * * * \\
(4.63)\end{array}$ & $\begin{array}{c}41.17^{* * *} \\
(3.21)\end{array}$ \\
\hline Observations & 251 & 263 & 251 & 263 & 262 & 255 \\
\hline Log Likelihood & -605.24 & 17.84 & -575.31 & -975.35 & -892.49 & -724.25 \\
\hline AIC. & $1,232.48$ & -13.68 & $1,172.61$ & $1,972.70$ & $1,806.99$ & $1,470.50$ \\
\hline $\mathrm{BIC}$ & $1,270.85$ & 25.23 & $1,210.99$ & $2,011.61$ & $1,845.85$ & $1,509.06$ \\
\hline
\end{tabular}

Note: ${ }^{*} \mathrm{p}<0.1 ;{ }^{* *} \mathrm{p}<0.05 ;{ }^{* * *} \mathrm{p}<0.01$. 
Table B4. Populism and liberal democracy by combinations of host ideology and government status.

\begin{tabular}{|c|c|c|c|c|c|c|}
\hline & VDem & UDS & DB & $\begin{array}{l}\text { Minority } \\
\text { Rights }\end{array}$ & $\begin{array}{c}\text { Mutual } \\
\text { Constraints }\end{array}$ & $\begin{array}{l}\text { Robustness Check } \\
\text { Mutual Constraints }\end{array}$ \\
\hline \multirow[t]{2}{*}{ Right Government } & $-2.51 * * *$ & $-0.20 * * *$ & $-2.58 * * *$ & $-9.15^{* * *}$ & -0.80 & -0.46 \\
\hline & $(0.86)$ & $(0.07)$ & $(0.88)$ & (3.34) & $(2.55)$ & $(1.52)$ \\
\hline \multirow[t]{2}{*}{ Center Government } & -0.04 & 0.03 & $0.91 *$ & 1.87 & -2.22 & -1.24 \\
\hline & $(0.52)$ & $(0.04)$ & $(0.50)$ & $(2.05)$ & $(1.57)$ & $(0.86)$ \\
\hline \multirow[t]{2}{*}{ Left Government } & $3.24 * * *$ & $0.28 * * *$ & 0.33 & $13.40 * * *$ & 1.50 & 1.67 \\
\hline & $(1.01)$ & $(0.08)$ & $(1.45)$ & (3.91) & (3.01) & (1.97) \\
\hline \multirow[t]{2}{*}{ Right Opposition } & $-1.12 * * *$ & -0.04 & -0.60 & $-3.50 * *$ & $-2.51 * *$ & -1.00 \\
\hline & $(0.42)$ & $(0.03)$ & (0.39) & $(1.59)$ & $(1.22)$ & $(0.68)$ \\
\hline \multirow[t]{2}{*}{ Center Opposition } & 0.52 & 0.03 & 0.38 & 1.79 & -0.67 & -0.14 \\
\hline & $(0.50)$ & $(0.04)$ & $(0.49)$ & $(1.96)$ & (1.49) & $(0.84)$ \\
\hline \multirow[t]{2}{*}{ Left Opposition } & $1.34^{* *}$ & 0.02 & -0.06 & $7.68 * * *$ & -0.53 & -0.48 \\
\hline & $(0.58)$ & $(0.05)$ & $(0.56)$ & $(2.23)$ & $(1.69)$ & $(0.95)$ \\
\hline \multirow[t]{2}{*}{ Democratic Consolidation } & $0.21 * * *$ & $0.004 * *$ & 0.01 & $0.44 * * *$ & $0.14 *$ & $0.18 * * *$ \\
\hline & $(0.03)$ & $(0.002)$ & $(0.03)$ & $(0.11)$ & $(0.07)$ & $(0.05)$ \\
\hline \multirow{2}{*}{ Cabinet Duration } & 0.02 & $0.002^{*}$ & $0.02 *$ & $0.09 * *$ & 0.03 & 0.02 \\
\hline & $(0.01)$ & $(0.001)$ & $(0.01)$ & $(0.04)$ & $(0.03)$ & $(0.02)$ \\
\hline \multirow{2}{*}{ Government Type (surplus) } & -0.19 & -0.01 & -0.54 & 0.26 & 1.36 & $1.30 * *$ \\
\hline & $(0.40)$ & $(0.03)$ & $(0.36)$ & (1.55) & (1.18) & $(0.63)$ \\
\hline \multirow[t]{2}{*}{ Economic Development } & -0.07 & 0.005 & $0.10 * *$ & $-0.40 * *$ & -0.06 & -0.07 \\
\hline & $(0.06)$ & $(0.003)$ & $(0.04)$ & $(0.18)$ & $(0.13)$ & $(0.07)$ \\
\hline \multirow[t]{2}{*}{ Post-Communist Country } & 0.95 & $-0.34 * * *$ & $-5.31 * *$ & $-24.96 * *$ & $11.25^{*}$ & 2.31 \\
\hline & (3.62) & $(0.12)$ & $(2.54)$ & (10.78) & $(5.81)$ & (4.70) \\
\hline \multirow[t]{2}{*}{ Constant } & $72.52 * * *$ & $1.22 * * *$ & $55.82 * * *$ & $66.11^{* * *}$ & $62.33^{* * *}$ & $41.05^{* * *}$ \\
\hline & $(2.53)$ & $(0.11)$ & (1.78) & (7.71) & $(4.62)$ & (3.25) \\
\hline Observations & 251 & 263 & 251 & 263 & 262 & 255 \\
\hline Log Likelihood & -601.04 & 19.31 & -570.74 & -966.41 & -885.56 & -718.38 \\
\hline AIC. & $1,230.09$ & -10.62 & $1,169.48$ & $1,960.82$ & $1,799.12$ & $1,464.75$ \\
\hline $\mathrm{BIC}$ & $1,278.76$ & 38.74 & $1,218.15$ & $2,010.18$ & $1,848.42$ & $1,513.65$ \\
\hline
\end{tabular}

Note: ${ }^{*} p<0.1 ; * p<0.05 ; * * *<0.01$. 
Table B5. RBC-association of populist parties with democratic quality by government status (lagged dependent variable model).

\begin{tabular}{|c|c|c|c|c|c|c|}
\hline & VDem & UDS & DB & $\begin{array}{l}\text { Minority } \\
\text { Rights }\end{array}$ & $\begin{array}{c}\text { Mutual } \\
\text { Constraints }\end{array}$ & $\begin{array}{l}\text { Robustness Check } \\
\text { Mutual Constraints }\end{array}$ \\
\hline Government & $\begin{array}{l}-0.20 \\
(0.37)\end{array}$ & $\begin{array}{l}-0.02 \\
(0.03)\end{array}$ & $\begin{array}{l}-0.41 \\
(0.31)\end{array}$ & $\begin{array}{l}2.18^{*} \\
(1.31)\end{array}$ & $\begin{array}{l}-1.22 \\
(1.27)\end{array}$ & $\begin{array}{l}-0.36 \\
(0.68)\end{array}$ \\
\hline Opposition & $\begin{array}{c}0.0000 \\
(0.27)\end{array}$ & $\begin{array}{c}0.0003 \\
(0.02)\end{array}$ & $\begin{array}{l}0.25 \\
(0.21)\end{array}$ & $\begin{array}{c}2.40 * * * \\
(0.91)\end{array}$ & $\begin{array}{l}-1.25 \\
(0.89)\end{array}$ & $\begin{array}{l}-0.53 \\
(0.48)\end{array}$ \\
\hline Democratic Consolidation & $\begin{array}{c}0.01 \\
(0.01)\end{array}$ & $\begin{array}{c}0.0001 \\
(0.0005)\end{array}$ & $\begin{array}{c}0.005 \\
(0.005)\end{array}$ & $\begin{array}{l}-0.03 \\
(0.02)\end{array}$ & $\begin{array}{l}-0.02 \\
(0.02)\end{array}$ & $\begin{array}{l}0.003 \\
(0.01)\end{array}$ \\
\hline Cabinet Duration & $\begin{array}{l}0.004 \\
(0.01)\end{array}$ & $\begin{array}{c}0.001 \\
(0.001)\end{array}$ & $\begin{array}{l}0.005 \\
(0.01)\end{array}$ & $\begin{array}{c}0.02 \\
(0.03)\end{array}$ & $\begin{array}{c}0.03 \\
(0.03)\end{array}$ & $\begin{array}{c}0.02 \\
(0.02)\end{array}$ \\
\hline Government Type (surplus) & $\begin{array}{c}0.06 \\
(0.30)\end{array}$ & $\begin{array}{c}0.04 \\
(0.02)\end{array}$ & $\begin{array}{c}0.06 \\
(0.24)\end{array}$ & $\begin{array}{c}0.64 \\
(1.07)\end{array}$ & $\begin{array}{c}0.70 \\
(1.06)\end{array}$ & $\begin{array}{c}0.51 \\
(0.57)\end{array}$ \\
\hline Economic Development & $\begin{array}{c}-0.001 \\
(0.02)\end{array}$ & $\begin{array}{c}0.003^{* *} \\
(0.001)\end{array}$ & $\begin{array}{l}0.003 \\
(0.01)\end{array}$ & $\begin{array}{l}-0.01 \\
(0.05)\end{array}$ & $\begin{array}{c}-0.005 \\
(0.05)\end{array}$ & $\begin{array}{c}0.01 \\
(0.03)\end{array}$ \\
\hline Post-Communist Country & $\begin{array}{c}0.36 \\
(0.44)\end{array}$ & $\begin{array}{l}-0.01 \\
(0.04)\end{array}$ & $\begin{array}{c}0.26 \\
(0.32)\end{array}$ & $\begin{array}{l}-1.84 \\
(1.47)\end{array}$ & $\begin{array}{c}0.17 \\
(1.45)\end{array}$ & $\begin{array}{c}0.18 \\
(0.75)\end{array}$ \\
\hline Lagged DV & $\begin{array}{c}0.96 * * * \\
(0.01)\end{array}$ & $\begin{array}{c}0.82 * * * \\
(0.04)\end{array}$ & $\begin{array}{c}0.96 * * * \\
(0.02)\end{array}$ & $\begin{array}{c}0.96 * * * \\
(0.02)\end{array}$ & $\begin{array}{c}0.81 * * * \\
(0.03)\end{array}$ & $\begin{array}{c}0.94 * * * \\
(0.03)\end{array}$ \\
\hline Constant & $\begin{array}{c}3.21 * * * \\
(1.14)\end{array}$ & $\begin{array}{c}0.17^{* * *} \\
(0.06)\end{array}$ & $\begin{array}{c}2.22 * * \\
(0.99)\end{array}$ & $\begin{array}{c}3.06 \\
(1.92)\end{array}$ & $\begin{array}{c}14.34 * * * \\
(3.23)\end{array}$ & $\begin{array}{l}2.56^{*} \\
(1.40)\end{array}$ \\
\hline Observations & 243 & 253 & 237 & 249 & 249 & 242 \\
\hline Adjusted $\mathrm{R}^{2}$ & 0.96 & 0.88 & 0.96 & 0.95 & 0.74 & 0.88 \\
\hline
\end{tabular}

Note: ${ }^{*} \mathrm{p}<0.1 ; * \mathrm{p}<0.05 ;{ }^{* *} \mathrm{p}<0.01$.

Table B6. RBC-association of populist parties with democratic quality by host ideology (lagged dependent variable model).

\begin{tabular}{|c|c|c|c|c|c|c|}
\hline & VDem & UDS & DB & $\begin{array}{l}\text { Minority } \\
\text { Rights }\end{array}$ & $\begin{array}{c}\text { Mutual } \\
\text { Constraints }\end{array}$ & $\begin{array}{l}\text { Robustness Check } \\
\text { Mutual Constraints }\end{array}$ \\
\hline \multirow[t]{2}{*}{ Right } & -0.32 & -0.03 & -0.13 & 0.11 & -0.44 & -0.01 \\
\hline & $(0.28)$ & $(0.02)$ & $(0.22)$ & $(0.93)$ & $(0.91)$ & $(0.48)$ \\
\hline \multirow[t]{2}{*}{ Center } & -0.23 & 0.02 & -0.04 & 0.30 & -0.70 & -0.48 \\
\hline & $(0.29)$ & $(0.02)$ & $(0.25)$ & $(1.05)$ & $(1.03)$ & $(0.55)$ \\
\hline \multirow[t]{2}{*}{ Left } & 0.35 & -0.01 & -0.06 & $2.84^{* *}$ & -0.50 & 0.12 \\
\hline & $(0.33)$ & $(0.03)$ & $(0.30)$ & $(1.20)$ & (1.17) & $(0.63)$ \\
\hline \multirow[t]{2}{*}{ Democratic Consolidation } & 0.004 & 0.0001 & 0.004 & -0.02 & -0.03 & 0.0004 \\
\hline & $(0.01)$ & $(0.0005)$ & $(0.005)$ & $(0.02)$ & $(0.02)$ & $(0.01)$ \\
\hline \multirow[t]{2}{*}{ Cabinet Duration } & 0.001 & 0.001 & 0.004 & 0.02 & 0.03 & 0.02 \\
\hline & $(0.01)$ & $(0.001)$ & $(0.01)$ & $(0.03)$ & $(0.03)$ & $(0.02)$ \\
\hline \multirow[t]{2}{*}{ Government Type (surplus) } & 0.13 & 0.03 & 0.04 & 1.30 & 0.60 & 0.59 \\
\hline & $(0.30)$ & $(0.03)$ & $(0.26)$ & (1.12) & (1.10) & (0.59) \\
\hline \multirow[t]{2}{*}{ Economic Development } & 0.01 & $0.003 * * *$ & 0.01 & 0.02 & -0.01 & 0.01 \\
\hline & $(0.02)$ & $(0.001)$ & $(0.01)$ & $(0.05)$ & $(0.05)$ & $(0.03)$ \\
\hline \multirow[t]{2}{*}{ Post-Communist Country } & 0.46 & -0.01 & 0.36 & -0.81 & -0.29 & -0.06 \\
\hline & $(0.43)$ & $(0.03)$ & $(0.32)$ & $(1.45)$ & $(1.42)$ & $(0.73)$ \\
\hline \multirow[t]{2}{*}{ Lagged DV } & $0.96 * * *$ & $0.82 * * *$ & $0.96 * * *$ & $0.96 * * *$ & $0.81 * * *$ & $0.93 * * *$ \\
\hline & $(0.01)$ & $(0.04)$ & $(0.02)$ & $(0.02)$ & $(0.03)$ & $(0.03)$ \\
\hline \multirow[t]{2}{*}{ Constant } & $3.48 * * *$ & $0.17 * * *$ & 1.85 & 2.79 & $14.57 * * *$ & $2.89 * *$ \\
\hline & $(1.15)$ & $(0.06)$ & (0.99) & (1.93) & $(3.26)$ & $(1.41)$ \\
\hline Observations & 243 & 253 & 237 & 249 & 249 & 242 \\
\hline Adjusted $\mathrm{R}^{2}$ & 0.96 & 0.88 & 0.96 & 0.95 & 0.74 & 0.87 \\
\hline
\end{tabular}

Note: ${ }^{*} \mathrm{p}<0.1 ; * \mathrm{p}<0.05 ;{ }^{* * *} \mathrm{p}<0.01$. 
Table B7. RBC-association of populist parties with democratic quality by combinations of host ideology and government status (lagged dependent variable model).

\begin{tabular}{|c|c|c|c|c|c|c|}
\hline & VDem & UDS & DB & $\begin{array}{l}\text { Minority } \\
\text { Rights }\end{array}$ & $\begin{array}{c}\text { Mutual } \\
\text { Constraints }\end{array}$ & $\begin{array}{l}\text { Robustness Check } \\
\text { Mutual Constraints }\end{array}$ \\
\hline \multirow[t]{2}{*}{ Right Government } & -0.34 & -0.05 & -0.24 & 0.41 & 0.91 & 1.11 \\
\hline & $(0.60)$ & $(0.05)$ & $(0.55)$ & $(2.27)$ & (2.17) & (1.29) \\
\hline \multirow[t]{2}{*}{ Center Government } & $-0.88 * *$ & -0.01 & $-0.67^{*}$ & -0.28 & -1.55 & -0.97 \\
\hline & $(0.43)$ & $(0.04)$ & $(0.38)$ & (1.61) & (1.56) & $(0.84)$ \\
\hline \multirow[t]{2}{*}{ Left Government } & $2.28 * * *$ & 0.05 & 0.82 & 2.74 & 2.53 & 1.83 \\
\hline & $(0.80)$ & $(0.07)$ & (1.58) & $(2.93)$ & (2.87) & (1.86) \\
\hline \multirow[t]{2}{*}{ Right Opposition } & -0.34 & -0.03 & -0.05 & 0.15 & -1.13 & -0.27 \\
\hline & $(0.28)$ & $(0.02)$ & $(0.22)$ & $(0.96)$ & (0.94) & $(0.50)$ \\
\hline \multirow[t]{2}{*}{ Center Opposition } & -0.20 & 0.02 & 0.10 & 0.85 & -0.95 & -0.58 \\
\hline & $(0.33)$ & $(0.03)$ & $(0.29)$ & (1.24) & $(1.22)$ & (0.65) \\
\hline \multirow[t]{2}{*}{ Left Opposition } & -0.03 & -0.02 & -0.10 & $2.85^{* *}$ & -1.07 & -0.09 \\
\hline & $(0.36)$ & $(0.03)$ & $(0.30)$ & $(1.33)$ & $(1.28)$ & (0.69) \\
\hline \multirow[t]{2}{*}{ Democratic Consolidation } & 0.01 & 0.0003 & 0.005 & -0.02 & -0.03 & -0.002 \\
\hline & $(0.01)$ & $(0.001)$ & $(0.005)$ & $(0.02)$ & $(0.02)$ & $(0.01)$ \\
\hline \multirow[t]{2}{*}{ Cabinet Duration } & 0.002 & 0.001 & 0.005 & 0.02 & 0.02 & 0.02 \\
\hline & $(0.01)$ & $(0.001)$ & $(0.01)$ & $(0.03)$ & $(0.03)$ & $(0.02)$ \\
\hline \multirow[t]{2}{*}{ Government Type (surplus) } & -0.03 & 0.02 & 0.05 & 1.11 & 0.35 & 0.45 \\
\hline & $(0.31)$ & $(0.03)$ & $(0.26)$ & (1.18) & (1.14) & $(0.61)$ \\
\hline \multirow{2}{*}{ Economic Development } & 0.002 & $0.003 * *$ & 0.005 & 0.01 & -0.01 & 0.01 \\
\hline & $(0.02)$ & $(0.001)$ & $(0.01)$ & $(0.05)$ & $(0.05)$ & $(0.03)$ \\
\hline \multirow[t]{2}{*}{ Post-Communist Country } & 0.39 & -0.01 & 0.33 & -0.96 & -0.21 & -0.08 \\
\hline & $(0.43)$ & $(0.03)$ & $(0.32)$ & (1.48) & (1.44) & $(0.75)$ \\
\hline \multirow[t]{2}{*}{ Lagged DV } & $0.96 * * *$ & $0.82 * * *$ & $0.96 * * *$ & $0.96 * * *$ & $0.82 * * *$ & $0.93 * * *$ \\
\hline & $(0.01)$ & $(0.04)$ & $(0.02)$ & $(0.02)$ & $(0.04)$ & $(0.03)$ \\
\hline \multirow[t]{2}{*}{ Constant } & $3.16^{* * *}$ & $0.17^{* * *}$ & $2.12^{* *}$ & 2.97 & $14.69 * * *$ & $3.15^{* *}$ \\
\hline & $(1.14)$ & $(0.06)$ & $(1.01)$ & (1.98) & (3.34) & $(1.52)$ \\
\hline Observations & 243 & 253 & 237 & 249 & 249 & 242 \\
\hline Adjusted $\mathrm{R}^{2}$ & 0.96 & 0.88 & 0.96 & 0.95 & 0.74 & 0.88 \\
\hline
\end{tabular}

Note: ${ }^{*} \mathrm{p}<0.1 ; * \mathrm{p}<0.05 ;{ }^{* * *} \mathrm{p}<0.01$. 
Table B8. RBC-populism and liberal democracy by government status using alternative coding (see notes below the table).

\begin{tabular}{|c|c|c|c|c|c|c|}
\hline & VDem & UDS & DB & $\begin{array}{l}\text { Minority } \\
\text { Rights }\end{array}$ & $\begin{array}{c}\text { Mutual } \\
\text { Constraints }\end{array}$ & $\begin{array}{l}\text { Robustness Check } \\
\text { Mutual Constraints }\end{array}$ \\
\hline \multirow[t]{2}{*}{ Government } & -0.41 & -0.004 & 0.37 & 2.38 & $-3.08 * *$ & $-1.81 * * *$ \\
\hline & $(0.45)$ & $(0.04)$ & $(0.42)$ & $(1.76)$ & $(1.27)$ & (0.69) \\
\hline \multirow[t]{2}{*}{ Opposition } & 0.28 & $0.05^{*}$ & 0.56 & $3.47 * *$ & $-1.96^{*}$ & $-1.05^{*}$ \\
\hline & $(0.38)$ & $(0.03)$ & $(0.34)$ & $(1.46)$ & $(1.06)$ & $(0.57)$ \\
\hline \multirow[t]{2}{*}{ Democratic Consolidation } & $0.19 * * *$ & $0.003 * *$ & 0.001 & $0.41 * * *$ & $0.13^{*}$ & $0.18^{* * *}$ \\
\hline & $(0.03)$ & $(0.002)$ & $(0.03)$ & $(0.11)$ & $(0.07)$ & $(0.05)$ \\
\hline \multirow[t]{2}{*}{ Cabinet Duration } & 0.01 & $0.001^{*}$ & 0.01 & $0.08^{*}$ & 0.04 & 0.02 \\
\hline & $(0.01)$ & $(0.001)$ & $(0.01)$ & $(0.04)$ & $(0.03)$ & $(0.02)$ \\
\hline \multirow[t]{2}{*}{ Government Type (surplus) } & 0.20 & 0.01 & -0.57 & 1.24 & $1.90 *$ & $1.63 * * *$ \\
\hline & $(0.40)$ & $(0.03)$ & $(0.36)$ & (1.56) & (1.12) & $(0.60)$ \\
\hline \multirow{2}{*}{ Economic Development } & -0.03 & $0.01 *$ & $0.10 * *$ & -0.30 & -0.05 & -0.07 \\
\hline & $(0.06)$ & $(0.003)$ & $(0.04)$ & $(0.19)$ & $(0.12)$ & $(0.07)$ \\
\hline \multirow[t]{2}{*}{ Post-Communist Country } & 1.60 & $-0.35 * * *$ & $-5.62 * *$ & $-23.45^{* *}$ & $11.55^{*}$ & 2.47 \\
\hline & (3.60) & $(0.11)$ & $(2.47)$ & $(10.82)$ & $(5.73)$ & (4.67) \\
\hline \multirow[t]{2}{*}{ Constant } & $71.59 * * *$ & $1.21 * * *$ & $55.95^{* * *}$ & $62.73 * * *$ & $61.99 * * *$ & $41.05^{* * *}$ \\
\hline & $(2.54)$ & $(0.10)$ & (1.74) & (7.79) & $(4.53)$ & (3.20) \\
\hline Observations & 251 & 263 & 251 & 263 & 262 & 255 \\
\hline Log Likelihood & -616.35 & 18.41 & -578.27 & -987.51 & -892.00 & -721.55 \\
\hline $\mathrm{AIC}$ & $1,252.71$ & -16.83 & $1,176.54$ & $1,995.02$ & $1,804.00$ & $1,463.09$ \\
\hline $\mathrm{BIC}$ & $1,287.64$ & 18.59 & $1,211.47$ & $2,030.44$ & $1,839.37$ & $1,498.19$ \\
\hline
\end{tabular}

Note: ${ }^{*} \mathrm{p}<0.1{ }^{* *} \mathrm{p}<0.05 ;{ }^{* * *} \mathrm{p}<0.01$.

For this robustness check, we recoded two cases where populist parties supported minority governments. These two cases were the Danish Peoples Party from 2001 to 2011 and the Dutch Freedom Party (PVV) from 2010 to 2012.

Table B9. Populism and liberal democracy by government status using seat share.

\begin{tabular}{|c|c|c|c|c|c|c|}
\hline & VDem & UDS & DB & $\begin{array}{l}\text { Minority } \\
\text { Rights }\end{array}$ & $\begin{array}{c}\text { Mutual } \\
\text { Constraints }\end{array}$ & $\begin{array}{l}\text { Robustness Check } \\
\text { Mutual Constraints }\end{array}$ \\
\hline \multirow[t]{2}{*}{ Government } & 0.62 & 0.16 & 0.40 & 8.91 & 0.42 & -0.09 \\
\hline & $(1.82)$ & $(0.15)$ & $(1.65)$ & (7.06) & (5.14) & $(2.86)$ \\
\hline \multirow[t]{2}{*}{ Opposition } & 1.94 & $0.35^{* *}$ & -2.04 & $18.53^{* *}$ & -5.08 & -1.50 \\
\hline & $(2.07)$ & $(0.17)$ & $(1.90)$ & $(8.03)$ & $(5.86)$ & $(3.30)$ \\
\hline \multirow[t]{2}{*}{ Democratic Consolidation } & $0.18^{* * *}$ & $0.003^{*}$ & 0.01 & $0.35 * * *$ & 0.12 & $0.17 * * *$ \\
\hline & $(0.03)$ & $(0.002)$ & $(0.03)$ & $(0.12)$ & $(0.07)$ & $(0.05)$ \\
\hline \multirow[t]{2}{*}{ Cabinet Duration } & 0.01 & $0.001^{*}$ & 0.02 & $0.08^{*}$ & 0.03 & 0.01 \\
\hline & $(0.01)$ & $(0.001)$ & $(0.01)$ & $(0.04)$ & $(0.03)$ & $(0.02)$ \\
\hline \multirow[t]{2}{*}{ Government Type (surplus) } & 0.20 & 0.02 & -0.58 & 2.00 & 1.38 & $1.40 * *$ \\
\hline & $(0.40)$ & $(0.03)$ & $(0.36)$ & $(1.55)$ & (1.13) & $(0.61)$ \\
\hline \multirow[t]{2}{*}{ Economic Development } & -0.02 & $0.01 *$ & $0.11^{* *}$ & -0.24 & -0.05 & -0.06 \\
\hline & $(0.06)$ & $(0.003)$ & $(0.04)$ & $(0.19)$ & $(0.12)$ & $(0.07)$ \\
\hline \multirow[t]{2}{*}{ Post-Communist Country } & 1.25 & $-0.37 * * *$ & $-0.19 * *$ & $-24.56 * *$ & $10.62 *$ & 1.80 \\
\hline & (3.59) & $(0.11)$ & $(2.49)$ & $(10.68)$ & $(5.81)$ & $(4.61)$ \\
\hline \multirow[t]{2}{*}{ Constant } & $71.92 * * *$ & $1.23^{* * *}$ & $55.87^{* * *}$ & $64.46 * * *$ & $62.05 * * *$ & $41.21^{* * *}$ \\
\hline & $(2.53)$ & $(0.10)$ & $(1.76)$ & $(7.72)$ & $(4.58)$ & (3.19) \\
\hline Observations & 251 & 263 & 251 & 263 & 262 & 255 \\
\hline Log Likelihood & -613.73 & 22.18 & -575.95 & -984.76 & -892.25 & -722.53 \\
\hline AIC & $1,247.45$ & -24.35 & $1,171.89$ & $1,989.51$ & $1,804.50$ & $1,465.05$ \\
\hline $\mathrm{BIC}$ & $1,282.38$ & 11.06 & $1,206.82$ & $2,024.93$ & $1,839.87$ & $1,500.15$ \\
\hline
\end{tabular}

Note: ${ }^{*} \mathrm{p}<0.1 ; * \mathrm{p}<0.05 ; * * \mathrm{p}<0.01$. 
Table B10. Populism and liberal democracy by host ideology using seat share.

\begin{tabular}{|c|c|c|c|c|c|c|}
\hline & VDem & UDS & DB & $\begin{array}{l}\text { Minority } \\
\text { Rights }\end{array}$ & $\begin{array}{c}\text { Mutual } \\
\text { Constraints }\end{array}$ & $\begin{array}{l}\text { Robustness Check } \\
\text { Mutual Constraints }\end{array}$ \\
\hline \multirow[t]{2}{*}{ Right } & $-7.94 * *$ & 0.03 & $-5.72 *$ & -5.42 & 0.36 & 1.57 \\
\hline & $(3.32)$ & $(0.27)$ & $(3.03)$ & $(13.20)$ & (9.84) & $(5.33)$ \\
\hline \multirow[t]{2}{*}{ Center } & 1.16 & 0.16 & 1.42 & 9.30 & -2.23 & -0.86 \\
\hline & $(1.74)$ & $(0.14)$ & $(1.60)$ & (6.98) & (5.19) & $(2.80)$ \\
\hline \multirow[t]{2}{*}{ Left } & $19.48 * * *$ & $1.13^{* * *}$ & -9.37 & $62.57 * * *$ & 0.93 & -0.43 \\
\hline & $(4.60)$ & $(0.36)$ & $(5.96)$ & $(17.80)$ & $(13.17)$ & (10.39) \\
\hline \multirow[t]{2}{*}{ Democratic Consolidation } & $0.17 * * *$ & 0.003 & 0.02 & $0.33^{* * *}$ & 0.11 & $0.16 * * *$ \\
\hline & $(0.03)$ & $(0.002)$ & $(0.03)$ & $(0.11)$ & $(0.07)$ & $(0.05)$ \\
\hline \multirow[t]{2}{*}{ Cabinet Duration } & 0.01 & 0.001 & 0.01 & $0.08^{*}$ & 0.03 & 0.01 \\
\hline & $(0.01)$ & $(0.001)$ & $(0.01)$ & $(0.04)$ & $(0.03)$ & $(0.02)$ \\
\hline \multirow[t]{2}{*}{ Government Type (surplus) } & 0.02 & 0.02 & $-0.66^{*}$ & 1.57 & 1.49 & $1.46 * *$ \\
\hline & $(0.38)$ & $(0.03)$ & $(0.36)$ & $(1.54)$ & $(1.15)$ & $(0.62)$ \\
\hline \multirow[t]{2}{*}{ Economic Development } & -0.02 & $0.01 *$ & $0.11^{* *}$ & -0.23 & -0.06 & -0.07 \\
\hline & $(0.05)$ & $(0.003)$ & $(0.04)$ & $(0.18)$ & $(0.12)$ & $(0.07)$ \\
\hline \multirow[t]{2}{*}{ Post-Communist Country } & 0.49 & $-0.39 * * *$ & $-4.96 *$ & $-26.19 * *$ & $10.13^{*}$ & 1.63 \\
\hline & (3.50) & $(0.12)$ & $(2.51)$ & $(10.62)$ & $(5.80)$ & (4.59) \\
\hline \multirow[t]{2}{*}{ Constant } & $72.71 * * *$ & $1.25^{* * *}$ & $55.69 * * *$ & $66.45 * * *$ & $62.34 * * *$ & $41.30 * * *$ \\
\hline & $(2.46)$ & $(0.10)$ & $(1.76)$ & $(7.67)$ & $(4.60)$ & (3.18) \\
\hline Observations & 251 & 263 & 251 & 263 & 262 & 255 \\
\hline Log Likelihood & -598.83 & 25.72 & -569.98 & -975.75 & -888.53 & -718.80 \\
\hline AIC & 1,219.67 & -29.43 & $1,161.96$ & $1,973.49$ & $1,799.07$ & $1,459.59$ \\
\hline $\mathrm{BIC}$ & $1,258.04$ & 9.48 & $1,200.34$ & $2,012.40$ & $1,837.93$ & $1,498.15$ \\
\hline
\end{tabular}

Note: ${ }^{*} \mathrm{p}<0.1 ; * \mathrm{p}<0.05 ; * * * \mathrm{p}<0.01$.

\section{Appendix C. Description of Control Variables and Rationale for Inclusion}

In our empirical model, we include a set of covariates that may relate to the presence of populist parties as well as to our democratic measures. This section in the Appendix explains the detailed rationale for the inclusion of each of the control variables. First, we include democratic consolidation as a control variable. We anticipate that both the existence of populism as well as the level of democracy might depend on how long a country is democratic. Furthermore, it has been argued elsewhere that the effect of populists is stronger when democratic institutions are less established (see Huber \& Schimpf, 2016b; Mudde \& Rovira Kaltwasser, 2012). To capture this logic, we use the time that has passed since democratization in each country was reached (in years) and use data from Polity IV (Marshall, Gurr, \& Jaggers, 2017). Second, we control for cabinet duration. The shorter a cabinet lasts, the less likely it is that a cabinet can realize its agenda. Third, we include a measure for cabinet composition. We distinguish between surplus governments and other governments such as minority or minimal winning coalitions. Albertazzi and Mueller (2013) as well as Huber and Schimpf (2016a) highlight that this might moderate the effect of populist parties in government. At the same time, long time surplus governments such as in Austria have been argued to provide fertile grounds for populist's anti-elite rhetoric. The ParlGov dataset contains information on, both, the cabinet duration and composition (Doering \& Manow, 2015). Fourth, we control for economic development. Some scholars have argued that populists are especially successful in garnering support from "losers of globalization" (Kitschelt, 1995, Kriesi et al., 2012). Thus, we anticipate that populist parties might be more successful in less developed countries. On the other hand, a long-lasting discussion has emerged on whether democracy and economic circumstances are connected or not (e.g. Boix \& Stokes, 2003, Przeworski, Alvarez, Cheibub, \& Limongi, 2000). To capture this, we measure economic development with Worldbank data on the gross domestic product per capita (GDPpc) in \$1000 to ease interpretation. Finally, we include a dummy for post-communist countries as we anticipate that this distinction might play a role, both in the existence of different populist parties and levels of democratic quality (Gherghina \& Soare, 2013, p. 7).

\section{References}

Albertazzi, D., \& Mueller, S. (2013). Populism and liberal democracy: Populists in government in Austria, Italy, Poland and Switzerland. Government and Opposition, 48(3), 343-371.

Boix, C., \& Stokes, S. C. (2003). Endogenous democratization. World Politics, 55(4) 517-549. 
Doering, H., \& Manow, P. (2015). Parliament and government composition database (ParlGov): An infrastructure for empirical information on parties, elections and governments in modern democracies. ParlGov. Retrieved from http://parlgov.org

Gherghina, S., \& Soare, S. (2013). Introduction: Populism-A sophisticated concept and diverse political realities. In S. Gherghina, S. Miscoiu, \& S. Soare (Eds.), Contemporary populism: A controversial concept and its diverse forms (pp. 1-15). Newcastle: Cambridge Scholars Publishing.

Huber, R. A., \& Schimpf, C. H. (2016a). A drunken guest in Europe? The influence of populist radical right parties on democratic quality. Zeitschrift für Vergleichende Politikwissenschaft, 10(2), 103-129.

Huber, R. A., \& Schimpf, C. H. (2016b). Friend or foe? Testing the influence of populism on democratic quality in Latin America: Populism and democracy. Political Studies, 64(4), 872-889.

Kitschelt, H., \& McGann, A. J. (1995). The radical right in Western Europe: A comparative analysis. Ann Arbor. MI: University of Michigan Press.

Kriesi, H., Grande, E., Dolezal, M., Helbling, M., Höglinger, D., Hutter, S., \& Wüst, B. (Eds.). (2012). Political conflict in Western Europe. Cambridge and New York, NY: Cambridge University Press.

Marshall, M. G., Gurr, T. R., \& Jaggers, K. (2017). Polity IV project: Political regime characteristics and transitions, 1800-2013: Dataset users' manual. Retrieved from http://www.systemicpeace.org/inscr/p4manualv2016.pdf

Mudde, C., \& Rovira Kaltwasser, C. (2012). Populism and (liberal) democracy: A framework for analysis. In C. Mudde \& C. Rovira Kaltwasser (Eds.), Populism in Europe and the Americas (pp. 113-136). Cambridge: Cambridge University Press.

Przeworski, A., Alvarez, M. E., Cheibub, J. A., \& Limongi, F. (2000). Democracy and development: Political institutions and well-being in the world, 1950-1990. Cambridge and New York, NY: Cambridge University Press. 